\title{
Assessment of factors affecting fire performance of mattresses: a review
}

\author{
Shonali Nazaré*, Rick D Davis and Kathryn Butler
}

\begin{abstract}
An in-depth analysis of U.S. residential fire statistics shows that although the total number of fires and deaths due to mattress fires has dropped as a result of several regulatory approaches, the mattress/bedding fires continue to account for one of the largest shares of residential fire deaths and injuries. To address the increasing number of deaths per 1000 mattress/bedding fires, the open flame mattress flammability regulation (16 CFR 1633) was introduced in 2007. The 16 CFR 1633 prescribes performance standards rather than design standards; this allows manufacturers the flexibility to meet the needs of the consumer without sacrificing fire safety. This flammability regulation for residential mattress has generated much interest in understanding the burning behavior of mattresses as well as in developing new materials for mattress construction. To comply with this regulation, it is essential to understand mattress construction, fire performance testing, factors affecting mattress flammability, and compliance solutions.

This report reviews the impact of current mattress flammability standards, examines factors affecting mattress flammability, and reviews full-scale and bench-scale test methods that are being developed for mattresses. The construction type, geometry, and size of a mattress are major factors in determining the fire threat of a mattress. The soft materials used in the mattress set, including cushioning materials, fire blocking materials, and tickings, act both individually and collectively to affect the fire performance. The performance of fire barrier materials designed to protect the inner cushioning material from heat and flame is largely dependent on the choice of cushioning material and ticking. When used with an incompatible combination of filling material and ticking, a fire barrier may fail to protect thermal degradation and subsequent burning of filling material. Some of the challenges in designing mattresses have been identified and reported here.
\end{abstract}

Keywords: Mattresses, Upholstered furniture, Flammability standards, Testing, Heat release rate, Ticking, Barrier fabric, Bedclothes

\section{Background}

Over the past three decades, the landscape of mattressrelated fires has significantly changed. In the U.S., numbers of mattress-related residential fires have consistently fallen with time. The credit for this improvement can be attributed in parts to factors including the introduction of: smoke detectors/alarms (Ahrens 2011a), smoldering ignition resistant mattresses regulated by 16 CFR 1632 (16 CFR 1632 Standard for the flammability of mattresses and mattress pads 1991), child-resistant lighter regulated by 16 CFR 1210 ( 1994), reduced ignition propensity cigarettes (Hall 2012), and other non-

\footnotetext{
* Correspondence: shonalisg@yahoo.com

National Institute of Standards and Technology, Engineering Laboratory, 100 Bureau Drive, Gaithersburg, MD 20899-8665, USA
}

regulatory factors including a general decline in smoking and wider awareness of fire safe behaviours (Tohamy \& Aiken 2007). Despite these approaches, mattresses/ beddings are still reported as the first items ignited in almost one-third of the fires originating in the bedroom and almost half of the associated deaths and injuries (Ahrens 2011b; Ahrens 2008; Greene \& Miller 2010).

The fire threat of a mattress is determined by the propensity of component materials to ignite, the intensity with which they burn and the rate at which flames spread. The cover fabric, which is often termed as ticking in the mattress industry, is a mattress component that can char, melt or ignite when in contact with an ignition source, for example, a smoldering cigarette or a small match flame. If the ticking forms a smoldering 
char, a considerable amount of heat may accumulate over a period of time and subsequently spread into the filling material. The ticking may also melt away from the ignition source, thereby exposing the underlying cushioning foam or filling. Smoldering may result in one of two possible outcomes as the heat penetrates into the filling: oxygen depletion may reduce the intensity of the ignition source and thereby extinguish the fire, or the filling material can ignite and fire begins to spread over the mattress assembly. Once the fire becomes an open flame, the bedclothes may catch fire and act as a high intensity secondary ignition source, leading to ignition of the underlying materials. The melting and dripping of the significant quantities of mattress components, such as polyester fiber batting and polyurethane foams may cause 'pool' fires thereby increasing the threat of fire spread to other items in the room (Fleischmann 2006). In addition to the direct threat of ignition, the hot gases and smoke from the burning bed assembly will accumulate under the ceiling. The temperature of this hot layer is very high, and its radiant heat can eventually ignite all flammable items in the room, leading to room flashover. Flashover typically occurs when the heat release from a burning bedding assembly reaches $1700 \mathrm{~kW}$ (Babrauskas et al. 2003). A fire of this size in a confined space results in rapid generation of carbon monoxide, which poses another serious threat to occupants elsewhere in the building. Mattresses related fire fatalities are often associated with fires with substantial growth or spread, such as a flashover (Ohlemiller \& Gann 2002). Thus, a bedding fire that begins with a smoldering cigarette or the open flame of a match has the potential to translate into a large fire with serious consequences (Ohlemiller \& Gann 2002).

New materials, constructions, and designs have been developed to meet the consumer's changing comfort and aesthetic needs while also addressing more rigorous flammability requirements from governmental regulatory agencies. Mattresses are complex products that are used by human beings for a long period of time during restful sleep. Generally the function of a residential mattress is to provide comfortable surface to rest or sleep. Mattresses used in public occupancies often have specific purposes and their functional requirements can be very different from the residential mattresses. Specific functions can be fulfilled with significant variations in construction geometries, support materials, cushioning materials, and textiles. Generally mattress manufacturers simply assemble mattress components acquired from more than a few suppliers. Besides very large mattress manufacturers who may have facilities to screen the component materials, small and medium sized mattress manufactures often rely upon their suppliers for component quality and compliance with specifications. The variability in the composition of these components and their assembly that may be introduced during construction may have significant impacts on the flammability properties of a mattress. In addition, the development of a fire is sensitive to the composition and geometric arrangement of the fuel. Construction variability can therefore not only significantly impact the fire behaviour of each component alone, but can also change the synergistic or antagonistic interactions of the components with each other. The interaction of all components in the final mattress set (mattress with foundation) is what ultimately determines the fire threat. The presence of bedclothes including sheets, blankets, bedspreads, pillows, and bed valances (also known as protective skirts) could also dictate or overwhelm mattress component interactions and hence the fire threat from mattresses.

This review considers the impact of current mattress flammability standards, examine factors affecting mattress flammability and review mattress flammability test methods and compliance solutions. This review is timely in light of the newly introduced flammability standard for mattresses (16 CFR 1633), and new materials and construction styles used to comply with this flammability standard.

\section{Mattress flammability regulations and test methods}

The majority of national and international mattress flammability standards and test methods listed in Table 1 are applicable to mattresses used in high occupancy public buildings. It is only in few developed countries (the U.S., Canada, UK, France and Norway) that residential mattresses have to comply with flammability regulations. In the United Kingdom the BS 6807 (BS 6807 2999) standard, now replaced by BS EN 597 (BS EN 597 2999), is used to assess the basic ignitability properties of mattresses and foundations using smoldering ignition source and an open flame ignition source. The open flame ignition source prescribed in BS EN 597 is a match flame equivalent and is much less severe as compared to the open flame ignition source described in CPSC's 16 CFR 1633 (16 CFR 1633 2007) regulation. Most European countries use EN 597 standard to evaluate ignitability of a mattresses. For mattresses used in high occupancy public buildings, for example in hotels, hospitals, and other public places, the BS 7177 (BS 7177 2999) standard specifies various combinations of ignition sources to represent four different hazard classifications as low, medium, high, or very high. The Canadian mattress flammability test (CAN2-4.2-M77 (1979)) is unique in that this is the only small-scale mock-up test to determine smoldering ignition resistance of a mattress and uses single lighted cigarette as smoldering ignition source. 


\begin{tabular}{|c|c|c|c|}
\hline $\begin{array}{l}\text { Issuing Authority/ } \\
\text { Country }\end{array}$ & $\begin{array}{l}\text { Standard Code } \\
\text { (Effective/Revised date) }\end{array}$ & Scope & Measured parameters \\
\hline \multicolumn{4}{|l|}{ United States } \\
\hline \multirow[t]{2}{*}{$\begin{array}{l}\text { Consumer Product Safety } \\
\text { Commission (CPSC) }\end{array}$} & 16 CFR 1632 & $\begin{array}{l}\text { Prescribes a test procedure for determination } \\
\text { of ignition resistance of residential mattress } \\
\text { when exposed to lighted cigarette. }\end{array}$ & Char length in any direction from the nearest point of the cigarette. \\
\hline & $\begin{array}{l}16 \text { CFR } 1633 \text { (Effective } \\
\text { July } 1,2007 \text { ) }\end{array}$ & $\begin{array}{l}\text { Standard for the flammability (open flame) } \\
\text { of residential mattress sets }\end{array}$ & Peak and total heat release rate. \\
\hline \multirow{8}{*}{$\begin{array}{l}\text { BHFTI (State of California, } \\
\text { Department of Consumer } \\
\text { Affairs) }\end{array}$} & Cal TB 129 & $\begin{array}{l}\text { Flammability test procedure for mattresses } \\
\text { for use in public buildings }\end{array}$ & $\begin{array}{l}\text { Peak and total heat release rate, mass loss in open (or furniture) } \\
\text { calorimetry test. }\end{array}$ \\
\hline & $\begin{array}{l}\text { Cal TB } 603 \text { (January 2005) ( now } \\
\text { superseded by } 16 \text { CFR 1633) }\end{array}$ & $\begin{array}{l}\text { Test procedure for open-flame fire testing of } \\
\text { residential mattresses under well-ventilated } \\
\text { conditions. }\end{array}$ & $\begin{array}{l}\text { Rate of heat release in oxygen consumption calorimetry and burning } \\
\text { behavior. }\end{array}$ \\
\hline & $\begin{array}{l}\text { Cal TB 604: (January 2005, Rule } \\
\text { making suspended in } \\
\text { March 29, 2010) }\end{array}$ & $\begin{array}{l}\text { Flammability (open flame) standard for filled } \\
\text { bedclothes: Comforters and bed spreads }\end{array}$ & \\
\hline & Section 1 & & Percentage weight loss \\
\hline & Section 2 & Pillows and bed cushions & Percentage weight loss \\
\hline & Section 3 & Mattress pads & Burning behavior \\
\hline & $\begin{array}{l}\text { Cal TB } 106 \text { Superseded by } \\
16 \text { CFR } 1632\end{array}$ & $\begin{array}{l}\text { Resistance of mattress or mattress pad to } \\
\text { cigarette ignition. }\end{array}$ & Char length in any direction from the nearest point of the cigarette. \\
\hline & Cal TB 121 & $\begin{array}{l}\text { Flammability of mattresses used in high risk } \\
\text { occupancies subjected to a galvanized metal } \\
\text { container with ten (10) double sheets of loosely } \\
\text { wadded news paper }\end{array}$ & Mass loss, change in temperature at the ceiling and CO production \\
\hline \multirow[t]{2}{*}{$\begin{array}{l}\text { Boston Fire Department } \\
\text { (Boston, Massachusetts) }\end{array}$} & $\begin{array}{l}\text { Boston Fire Department } \\
\text { Method IX-11 }\end{array}$ & $\begin{array}{l}\text { Mattresses (with bedclothes) intended for use } \\
\text { in health care facilities, hotels and dormitories }\end{array}$ & Full scale burning behavior using furniture calorimeter \\
\hline & Michigan Roll-Up Test & For mattresses used in jails & $\begin{array}{l}\text { Mattress or pads are rolled up, tied and stuffed with newspaper and } \\
\text { leaned against the bed frame. There is no specified test criteria }\end{array}$ \\
\hline \multirow[t]{3}{*}{$\begin{array}{l}\text { American Standard Test } \\
\text { Methods (ASTM) }\end{array}$} & ASTM E-1590 & $\begin{array}{l}\text { Standard test method for determination of burning } \\
\text { behavior of mattresses used in public occupancies }\end{array}$ & $\begin{array}{l}\text { Rate of heat release by an oxygen consumption method, production } \\
\text { of light-obscuring smoke and the concentrations of certain toxic gas } \\
\text { species in the combustion gases }\end{array}$ \\
\hline & ASTM D 7140 & $\begin{array}{l}\text { Test method to measure heat transfer through } \\
\text { textile thermal barrier materials. }\end{array}$ & $\begin{array}{l}\text { Heat transfer properties of barrier material when exposed to a } \\
\text { calibrated convective and radiant energy heat source for } 60 \text { seconds }\end{array}$ \\
\hline & ASTM D 7016 & $\begin{array}{l}\text { Test method to evaluate edge binding components } \\
\text { (e.g. thread, tape)used in mattresses after exposure } \\
\text { to an open flame }\end{array}$ & $\begin{array}{l}\text { Flammability characteristics of mattress edge bindings and sewing } \\
\text { threads during and after exposure to an open flame ignition source. }\end{array}$ \\
\hline $\begin{array}{l}\text { National Fire Protection } \\
\text { Association (NFPA) }\end{array}$ & NFPA 267 & $\begin{array}{l}\text { Standard method of test for fire characteristics of } \\
\text { mattresses and bedding assemblies exposed to } \\
\text { flaming ignition source }\end{array}$ & $\begin{array}{l}\text { Heat release, smoke density, weight loss, and generation of carbon } \\
\text { monoxide of mattresses and bedding assemblies using an open } \\
\text { calorimeter environment. }\end{array}$ \\
\hline
\end{tabular}


Table 1 Standards and test methods for mattress and beddings (Continued)

\begin{tabular}{|c|c|c|c|}
\hline \multicolumn{4}{|l|}{ International } \\
\hline \multicolumn{4}{|l|}{ Canada } \\
\hline \multirow[t]{3}{*}{$\begin{array}{l}\text { Underwriters' } \\
\text { Laboratories (UL) }\end{array}$} & CAN/ULC-S137 & $\begin{array}{l}\text { Standard test method for fire growth of mattresses } \\
\text { (open flame test) }\end{array}$ & $\begin{array}{l}\text { Measures PHRR, THR and mass loss when subjected to a specified } \\
\text { flaming ignition source under well ventilated conditions }\end{array}$ \\
\hline & UL 1895 & Fire tests of mattresses & $\begin{array}{l}\text { Investigates the ability of a mattress to resist rapid heat release when } \\
\text { subjected to a flaming ignition source }\end{array}$ \\
\hline & UL 2060 (withdrawn) & $\begin{array}{l}\text { Standard for fire test of mattresses with bedclothes } \\
\text { using a furniture calorimeter }\end{array}$ & $\begin{array}{l}\text { Investigates the ability of a mattress to resist rapid heat release when } \\
\text { subjected to a flaming ignition source }\end{array}$ \\
\hline \multicolumn{4}{|l|}{ United Kingdom } \\
\hline \multirow{5}{*}{$\begin{array}{l}\text { British Standards } \\
\text { Institution (BS) }\end{array}$} & BS EN 597: 1995 & Assessment of the ignitability of mattress sets & Burning behavior: Unsafe escalating combustion \\
\hline & \multirow[t]{2}{*}{ (Replaced BS 6807:1990) } & \multirow{2}{*}{$\begin{array}{l}\text { Ignition source: smoldering cigarette. Match } \\
\text { flame equivalent }\end{array}$} & Smoldering through thickness Char length \\
\hline & & & Flaming ignition in case of match-flame equivalent ignition source \\
\hline & BS 7177:2008 & $\begin{array}{l}\text { Specification for resistance to ignition of mattresses, } \\
\text { mattress pads, divans and bed bases }\end{array}$ & - \\
\hline & BS 7175:1989 & $\begin{array}{l}\text { Methods of test for the ignitability of bedcovers and } \\
\text { pillows by smoldering and flaming ignition sources }\end{array}$ & $\begin{array}{l}\text { Burning behavior observed for : Hole formation, melting, dripping, } \\
\text { charring, ignition and development of flames from smoldering. }\end{array}$ \\
\hline \multicolumn{4}{|l|}{ Sweden } \\
\hline \multirow{2}{*}{$\begin{array}{l}\text { Swedish Standards Institute/ } \\
\text { Sweden }\end{array}$} & SS EN 597:1994 & Same as BS EN $597: 1995$ & \\
\hline & SS 8760010 & Hospital beds, high performance & \\
\hline \multicolumn{4}{|l|}{ Denmark } \\
\hline Denmark & NT FIRE 037 & $\begin{array}{l}\text { Procedure to determine the ignitability of bedclothes, } \\
\text { including mattress pad with small smoldering and } \\
\text { flaming sources of ignition. }\end{array}$ & Individual component test \\
\hline \multicolumn{4}{|l|}{ Germany } \\
\hline $\begin{array}{l}\text { German Institute of } \\
\text { Standards (DIN) }\end{array}$ & DIN EN 14533 & $\begin{array}{l}\text { Textiles and textile products - Burning behavior of } \\
\text { bedding items - Classification scheme }\end{array}$ & - \\
\hline \multicolumn{4}{|l|}{ Others } \\
\hline $\begin{array}{l}\text { International Maritime } \\
\text { Organization (IMO) }\end{array}$ & $\begin{array}{l}\text { IMO MSC. 61(67), Annex 1, } \\
\text { Part 9, MO Res A.688 (17) }\end{array}$ & Ignitability of bedding components & As mentioned in NFPA 267, ASTM 159016 CFR 1633 \\
\hline ISO & ISO 12952-2:1998 & $\begin{array}{l}\text { Burning behavior of bedding items - Part 2: Specific } \\
\text { test methods for the ignitability by a smoldering } \\
\text { cigarette }\end{array}$ & Char length, smoldering and formation of holes \\
\hline
\end{tabular}


Generally, mattress flammability standards prescribe fullscale testing of a prototype mattress (mattress without bedclothes) when exposed to different ignition sources. The ignition sources defined for the mattress flammability test in Table 1 represent the fire hazard of a mattress. For example, the Michigan Roll-up test defined by the Boston Fire Department, U.S., requires testing of mattresses used in jails to be tested as rolled up mattresses stuffed with newspaper. This configuration of mattress and ignition source (burning newspaper) represents a fire hazard stemming from a deliberate, representative act.

The fire performance of mattresses is regulated in the United States using two types of ignition source; smoldering and open flame ignition. The current U.S. mattress flammability standards that have the most significant impact on industry and the consumer are 16 CFR 1632 (16 CFR 1632 Standard for the flammability of mattresses and mattress pads 1991) and 16 CFR 1633(16 CFR 1633 2007). The two federal flammability regulatory standards (16 CFR 1632 and 16 CFR 1633) are mandatory, and all manufacturers must comply with them in order to sell residential mattresses in the U.S. (Table 1). The 16 CFR 1632 regulation, introduced by the Consumer Product Safety Commission (CPSC) in 1973, defines the fire resistance of mattresses to cigarette ignition, a smoldering source. The smoldering ignition test measures the char length over the mattress surface and the extent of damage to the mattress after a specified time period (Table 1).

The 16 CFR 1633 regulation defines the resistance of mattresses to open flame ignition sources. Prior to the introduction of 16 CFR 1633 in 2007, the Cal TB 603 (Table 1) was adopted in the state of California and regulated by the Bureau of Electronic and Appliance Repair, Home Furnishings and Thermal Insulation (BHFTI). The fire behavior aspects that are generally examined for an open flame ignition test include the heat release rate (HRR), the time and level of the peak heat release rate (PHRR), the total heat released (THR), the rate of flame spread, and the mass loss a specified time period (Table 1). Mattresses or bedding assemblies are placed on top of a large load cell during the flammability test to measure sample weight as a function of time. The test method described in 16 CFR 1633 uses dual T-shaped propane burners with a heat flux of $65 \mathrm{~kW} / \mathrm{m}^{2}$ and $45 \mathrm{~kW} / \mathrm{m}^{2}$ for top and side burners respectively. The top surface of the mattress is exposed to the burner for 70 seconds, and the side is exposed for 50 seconds. The ignition source was designed and developed by NIST (Ohlemiller et al. 2000; Ohlemiller 2003) to replicate the impact of burning bedclothes on mattresses. The test criteria are that the THR shall not exceed $15 \mathrm{MJ}$ for the first 10 min of the test, and that the PHRR shall not exceed $200 \mathrm{~kW}$ at any time in the 30 minute test. Heat release rate is measured by oxygen consumption calorimetry, either in an open hood environment or inside a room.

Both mattress flammability standards, 16 CFR 1632 and 16 CFR 1633, require full scale testing of all prototype mattresses or mattress sets introduced for sale in the United States. In order to minimize the testing burden on the manufacturer, a representative mattress or mattress set to be placed on the market can be tested. If this sample meets both cigarette ignition resistance and open flame ignition resistance test criteria, it then becomes a 'qualified prototype' that can be used as a model for the production of these mattresses, as long as the materials, components, design, and method of assembly remain unchanged. Furthermore, manufacturers have been granted the flexibility to produce similar mattresses of differing sizes and to use materials, components, and methods of assembly whose FR performance is similar to or better than the qualified prototype. Such 'subordinate prototypes' do not require additional testing as long as a record of the manufacturing specification and a description of the variation from the 'qualified prototype' are available. The manufacturer is also required to show sufficient documented evidence that the changes in the subordinate prototype will not cause the prototype to exceed the specified test criteria. There also exists a possibility of 'pooling' the qualified prototypes, whereby two or more manufacturers can use qualified prototypes to produce mattress sets. When using pooled prototypes, manufacturers are required to conduct one successful confirmation test. Prototype pooling is only permitted by 16 CFR 1633 however, to improve testing efficiencies and reducing testing burden, International Sleep Product Association (ISPA) has suggested extending the prototype pooling concept to 16 CFR 1632 ( 2005).

Besides, there are only few test methods developed to evaluate burning behavior of mattress components such as textile thermal barrier materials (ASTM D 7140), sewing thread, tape and edge components (ASTM D 7016). Germany has classification scheme for bedding components based on DIN EN 14533 (BS EN 14533 2003) whereas NT FIRE 037 (Table 1) determines ignitability of bedclothes including mattress pads. Standards and test methods listed in Table 1 may be mandatory or voluntary. Mandatory standards, also known as regulatory standards, are incorporated into government regulations with which products must comply. Voluntary standards are often used for quality control in industry or for development of new products.

\section{Impact of flammability regulations on fire statistics}

Across the world, very few comprehensive statistics exist, especially those which attempt to relate deaths and injuries to first items of ignition in residential buildings. 
International reporting of fire statistics is not standardized and no common international basis exists for the gathering and interpreting of such information. Systematic fire incidence reporting system is now well established in the US, UK and Canada and by far shows residential/ furnishing fires to be significant cause of fire deaths. This section focuses primarily on impact of mattress flammability regulations on fire statistics.

Figure 1a shows number of mattress/bedding related fires in US residential buildings. Generally, a downward trend is seen in number of mattress/bedding related fires. A significant decrease in number of fires (Figure 1a), number of personal injuries (Figure 1b) and fatalities (Figure $1 \mathrm{c}$ ) in residential fires starting with smoking material as ignition source was observed beginning in the early 1980s, almost ten years after the introduction of the smoldering ignition performance regulation (16 CFR 1632) ( 2007a). The continuing decrease in the number of such fires over the next two decades can be attributed at least in part to 16 CFR 1632. However, other changes over this period, including the introduction of smoke alarms/detectors, reduced ignition propensity cigarettes in 2004 (Hall 2012) and the reporting methodology for generating fire statistics (U.S. Fire Administration National Fire Data Center 2008), make it difficult to separate out its specific contribution. Also, it is important to note that the number of fires in fire statistics include only reported fires. Some successfully terminated fires never get reported as is the case with smoke alarms as well. In the presented fire statistics (2007a), intentional fires and their associated losses, which include the deliberate misuses of heat sources, or fires of an incendiary nature, are excluded.

For open flame ignition, the number of residential mattress/bedding-related fires decreased significantly between 1980 and 2006. This decrease in open flame ignition fires is associated with the introduction of CPSC's childresistant lighter regulation (16 CFR Part 1210 (1994)) in 1994 (Smith et al. 2002) and wider dissemination of safe behaviors regarding match and lighter storage and display around children (out of sight and out of reach) (Smith et al. June 1991). However, the average number of civilian deaths and injuries showed a downward trend with large year-to-year fluctuations. From Figure 1b it appears that, 1992 onwards, the open flame ignition fires caused higher number of civilian injuries compared to those caused due to smoldering ignition fires suggesting that the, open flame ignition represents a more immediate hazard than smoldering ignition. By 2006, however, the combination of 16 CFR 1632, low smoldering cigarettes, and other factors had significantly reduced all such losses - by $93 \%$ in the number of fires and $73 \%$ and $68 \%$ in the number of civilian injuries and deaths respectively.

The U.S. fire statistics ( 2007b) for all residential fires include a breakdown of ignition sources, permitting fires from smoldering sources (cigarettes) to be distinguished from those from open flame sources (matches, lighters, and candles). The incidence reporting system (U.S. Fire Administration National Fire Data Center 2008) however does not differentiate between bedding and mattress fires. Figure 2a shows that the number of residential fires caused by smoldering cigarettes has decreased much more than the number of fires caused by flaming ignition sources. The number of personal injuries caused by open flame ignition sources has decreased by less than those caused due to smoldering ignition sources (Figure 2b). However, deaths from cigarettes continue to be a factor of 2 higher (Figure 2c).

In 1994, for the first time since fire losses have been tracked at this level of detail, there were more mattressbedding fires caused by open flame ignition sources than by smoking materials (Figures $1 \mathrm{a}$ and $2 \mathrm{a}$ ). It is also important to note from Figure $2 \mathrm{a}$ that the number of mattressbedding fires starting from open flames of lighters and matches have decreased. Meanwhile, candle fires were trending upwards for a number of years. Other studies have also shown an increasing trend towards open flame bedding fires ( 2002a; Nurbakhsh \& Mc Cormack 1998). As mentioned earlier, open flame ignition represents a more immediate hazard than smoldering ignition. Smoldering fires on mattress may take 25 minutes or longer to transition into flames, the point at which mattress fires ignited by open flames begin (Ohlemiller \& Gann 2002). Open flame fires provide a short time window for detection, escape and fire response. Moreover, despite the drop in the total number of fires and deaths due to mattress fires (2007a), deaths per 1000 mattress/bedding fires have increased with time (Figure 3). An increase in number of deaths per 1000 mattress/bedding fires suggests that the regulatory and non-regulatory changes have had a disproportionally greater impact on smaller, non-casualty fires, that is, they have reduced small fires much more than large fires, resulting in an increase in casualty rates but not in casualties.

This was one of the motivations for CPSC to introduce a sister regulation to 16 CFR 1632, which defined the open flame performance of mattresses (16 CFR 1633). All mattresses brought into the U.S. market since 2007 have been required to comply with 16 CFR 1633 . While it is expected that 16 CFR 1633 will significantly reduce fire losses, the true impact of this standard is not expected to be realized for at least another 5 to 10 years, after a majority of old non-compliant mattresses are replaced with new compliant ones (Tohamy 2999). Increase in number of deaths per 1000 mattress/bedding fires could also be due to increased fire hazard of bedclothes. Bedclothes flammability studies (Ohlemiller 2005; Ohlemiller \& Gann 2003; Butler et al. 2999) have shown that bedclothes have the potential to result in 


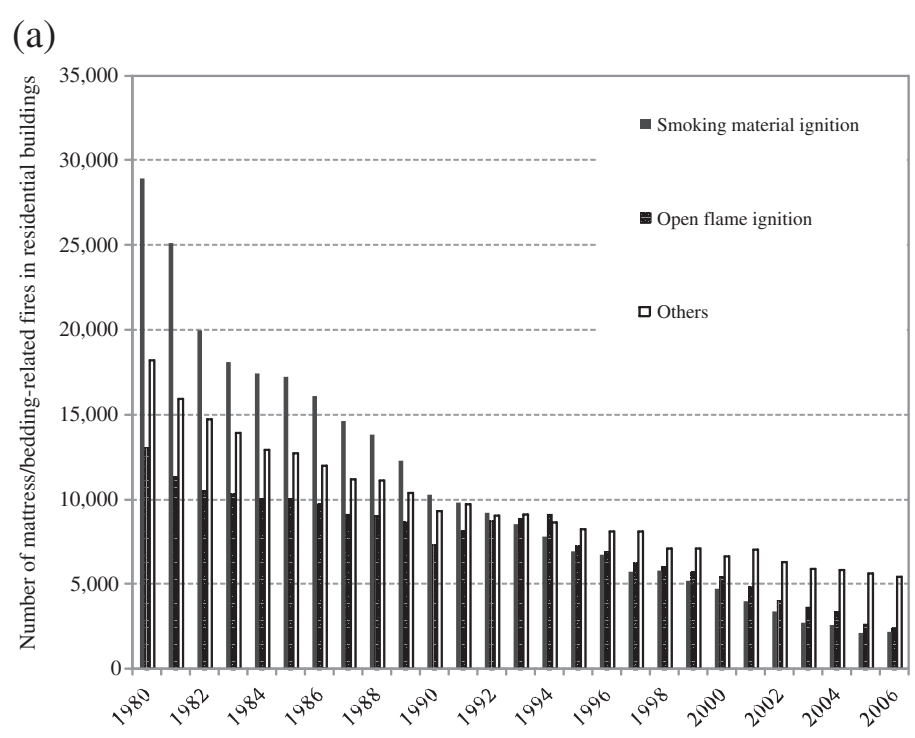

(b)

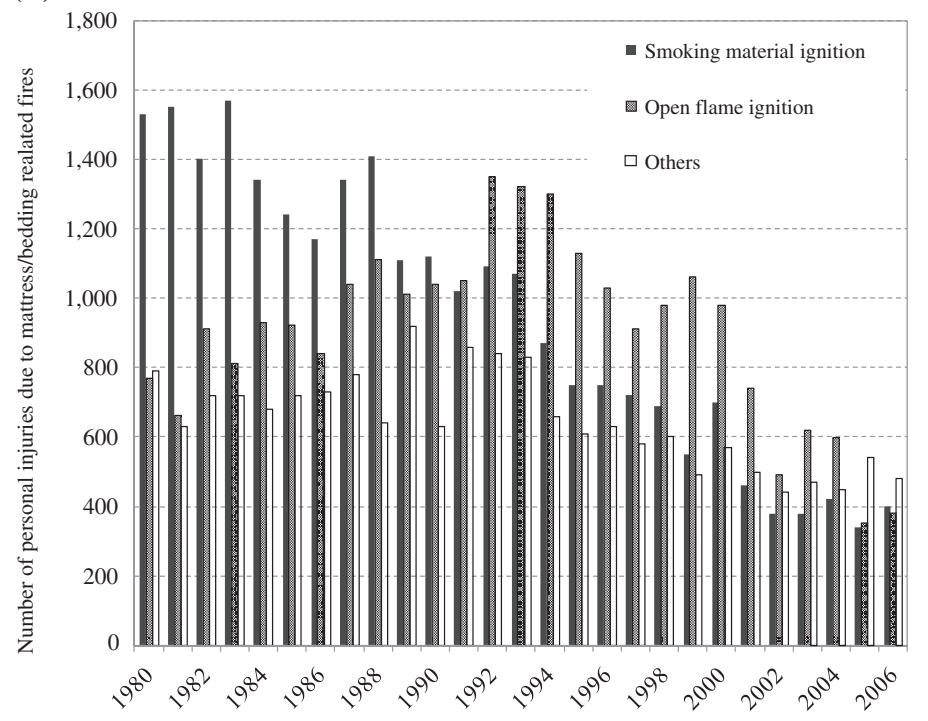

(c)

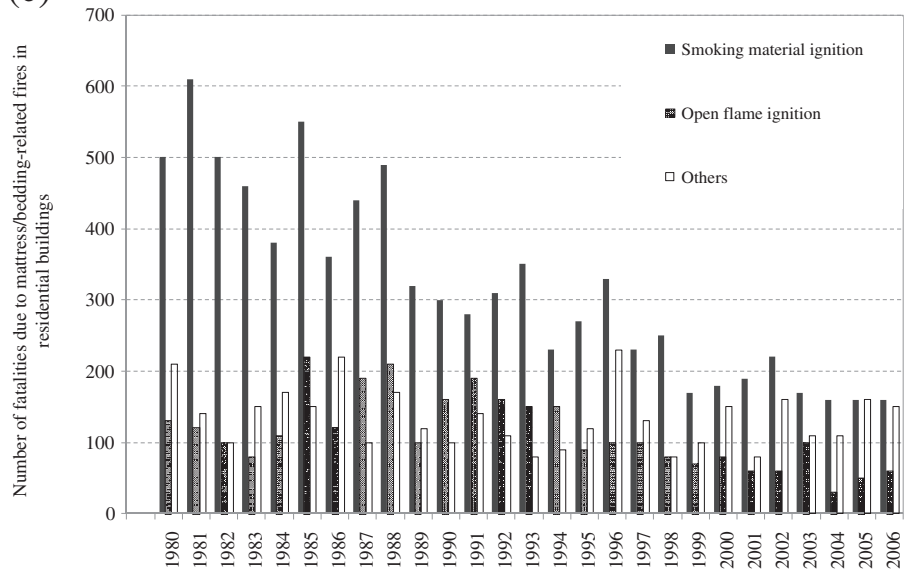

Figure 1 (See legend on next page.) 
(See figure on previous page.)

Figure 1 Mattress-bedding related US residential fire losses from 1980 to 2006, delineated by ignition source. Number of (a) fires, (b)

civilian injuries, and (c) civilian fatalities (2007a).

flashover in a few minutes after ignition. Formal regulation of flammability of bedclothes (Cal TB 604, see Table 1) was proposed by the BHFTI in the state of California, but this is now suspended ( 2999a). The Canadian Underwriters' Laboratories (UL) developed test methods for mattresses with bedclothes (UL 2060) which is also withdrawn (2002) (2999b).

Both 16 CFR 1632 and 16 CFR 1633 are performance standards rather than design standards. They do not address specific approaches for achieving compliance (such as through barrier materials or fire retardants); instead, they describe how to conduct the tests and provide pass/fail criteria. This allows manufacturers the flexibility to meet the needs of the consumer without sacrificing fire safety. To comply with these standards, it is essential to understand mattress construction, fire performance testing, factors affecting mattress flammability, and compliance solutions. These topics are discussed in the following sections.

\section{Mattress construction and component materials}

The variations in size, geometry, and construction of mattress sets are reasonably well standardized within the mattress industry and available number of variation are given in Table 2. The soft components of a mattress are manufacturer-dependent, with many highly engineered combinations of fibers, fabrics and foam available. Excluding ticking variations, mattresses are available in several thousand variations of design and construction (Table 2). The primary components of mattresses are described below.

\section{Frame and foundation}

A typical mattress set consists of three components: the frame, foundation and mattress (Figure 4). The frame is the support for a mattress set and is usually constructed from wood or metal.

The purpose of a foundation is to provide support to the mattress, enhance mattress performance, and extend the service life of a mattress. The foundation and mattress are generally paired as a matched set. Using a foundation that is not well-matched with the mattress can decrease mattress performance and service life, and may also affect the fire performance of the mattress set. The most common type of foundation is a rigid non-yielding foundation (e.g. box spring ) (Figure 4), which is constructed of several springs or shock absorbing torsion modules mounted on a rigid metal support. The boxspring is covered by a ticking, which usually matches the ticking fabric of a mattress. Foundations with foam filling and cotton battings have also been reported but are becoming obsolete in modern mattress sets.

\section{Mattress support system}

Mattresses are classified by the type of support system: innerspring, solid foam, cotton batting, air, or water. Air and water mattresses account for less than $20 \%$ of the U.S. market, solid foam (viscoelastic and latex) mattresses and innerspring mattresses account for nearly all of the remaining $80 \%$ of the U.S. market (Mattress manufacturing in the US 2011). Solid foam mattresses, also called allfoam mattress, do not have springs or other metallic arrangements. The use of viscoelastic or 'memory' foam and latex mattress is increasing in modern residential mattresses. An innerspring mattress is constructed from metal springs that may be separately housed in individual fabric sheaths or attached to a metal frame (Figure 4a). Innerspring mattresses covered with varying combinations of layered viscoelastic and latex foam in combination with standard PUF are also available. For single-sided mattresses (also known as 'no flip' mattresses), the innerspring is covered by a comfort layer on one side and a low-cost non-woven backing material on the other. A comfort layer covers both sides for double-sided mattresses.

\section{Cushioning and comfort layer}

The comfort layer is divided into three subcategories: the quilt, the insulating layer, and the cushioning layer. The quilt is the top layer of the mattress. It provides a soft surface texture and a level of firmness that can be varied by changing the material and the details of construction. The quilt consists of the ticking plus low-density foam or fiber batting that is stitched to its underside. These two layers are sewn to a tape edge that attaches to the border quilting around the perimeter of the mattress. The insulating layer is the first layer next to the innerspring unit. It forms a barrier between the softer foam layers to reduce the likelihood of them "pocketing" into the spring unit and causing a lumpy uncomfortable sleeping surface. The insulating layer can be a fiber batting or layers of non-woven fabrics. The cushioning layer provides an extra layer of comfort, and may include flat or convoluted PUF, shredded pads of compressed polyester, or fiber battings. The insulator and cushioning layers can be stacked in varying sequences between the quilt and the innerspring support. With the introduction of 16 CFR 1633 in 2007, most mattress manufacturers changed to single-sided mattresses 


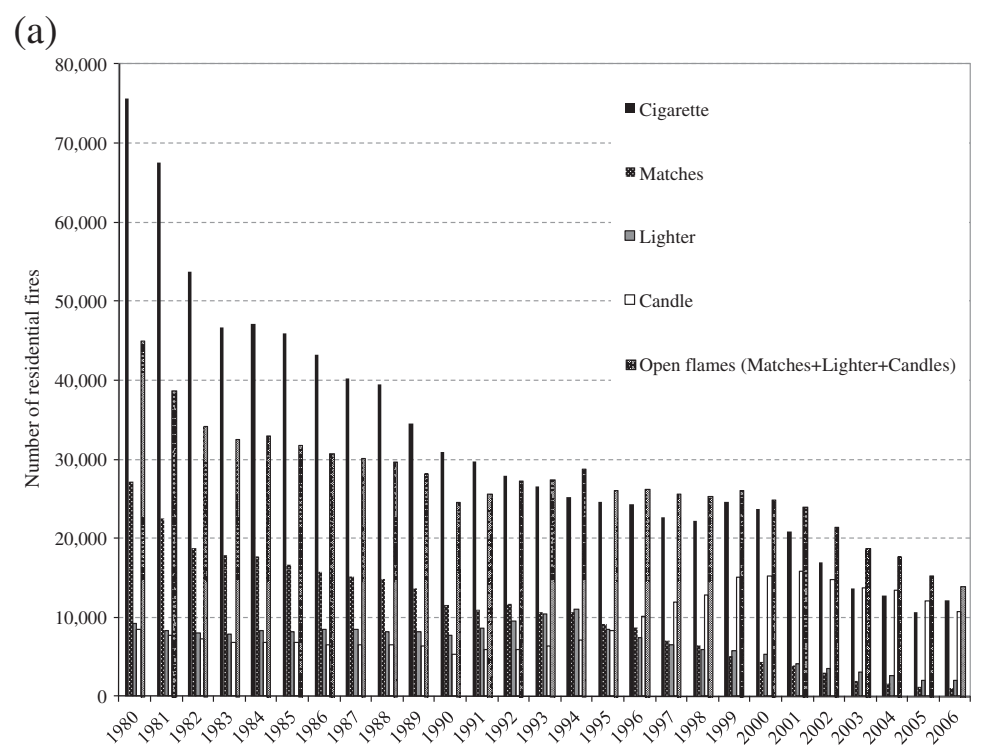

(b)

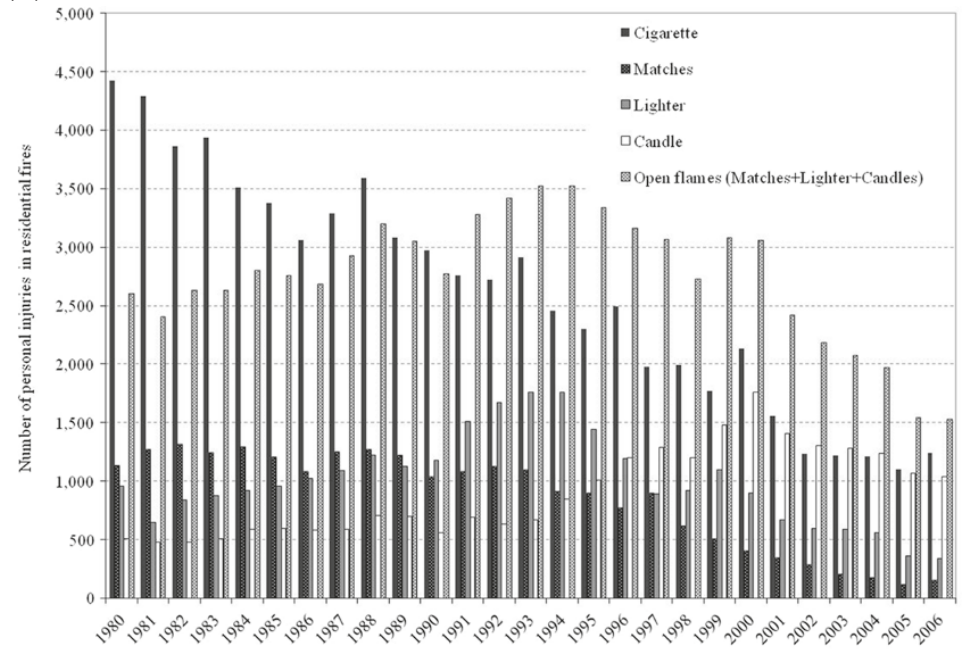

(c)

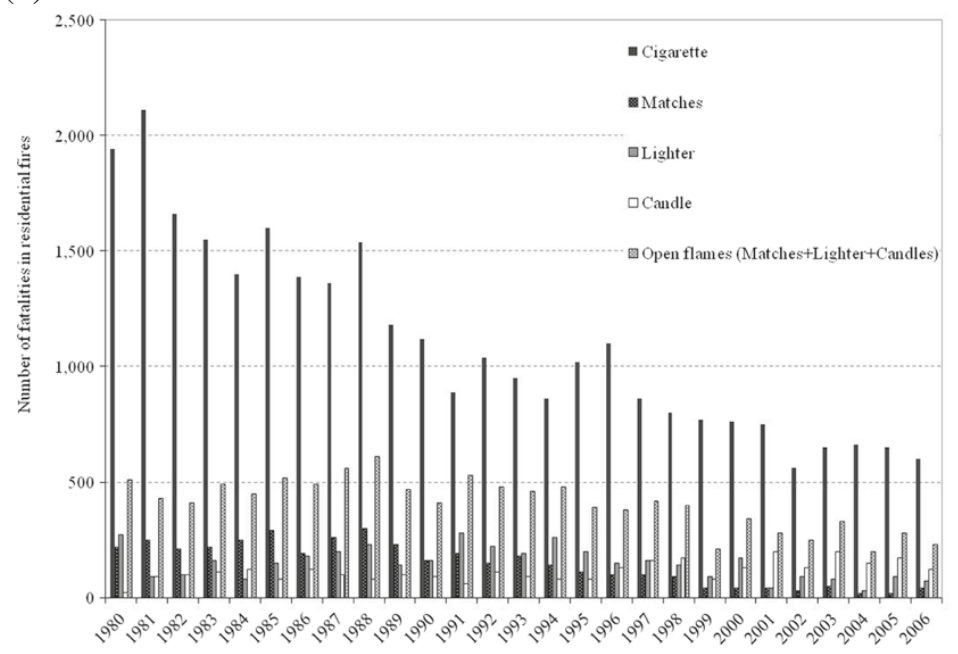

Figure 2 (See legend on next page.) 
because of the expense of complying with flammability regulations for both sides of the bedding (Taylor 2999).

\section{Fire blocking materials}

The purpose of fire blocking materials is to reduce the flammability of soft furnishings by preventing or delaying direct flame impingement and heat transfer from the flames to the core cushioning components. A variety of fire blocking technologies using various types of fabrics and fibers has been developed. A detailed review is available that covers fire blocking mechanisms and technologies used in soft furnishings in general (Nazare \& Davis 2011). In this section, fire blocking materials that are specifically used for mattress applications are discussed.

Fire blocking materials were commonly used in institutional mattresses that are required to pass the open flame ignition resistance test. However with the introduction of the 16 CFR 1633 regulation, the immediate response to comply with the regulation was to introduce fire blocking materials in residential mattress construction. The fire barrier is strategically placed between the sacrificial quilt layer and the cushioning layer.

Institutional mattresses use both active and passive fire blocking technologies. A passive fire barrier is made from inherently fire resistant fibers. It serves as a physical and/or thermal barrier between some or all of the fuel and the potential ignition source. Glass fiber battings or woven glass fiber fabrics are commonly used in institutional mattresses, although fiberglass flame barriers have disadvantages of poor durability (due to glassto-glass abrasion) and lack of resiliency. Active fire blocking can be achieved through a fire retardant (FR) coating on a glass fiber substrate. These barrier materials have a chemical effect on the fire. They can alter the pyrolysis process to reduce the amount of flammable volatiles and suppress the flames from the ignition source, prevent the ticking from burning, and prevent the ignition of interior cushioning material.

Thermally thin fire barrier fabrics are not recommended in public occupancies that have a relatively high risk of vandalism, such as prisons and mental hospitals. In public institutions with high risk occupancies, densified polyester batting is often used as a filling material instead of highly flammable foam. Densified polyester batting is difficult to ignite as the thermoplastic polyester melts and shrinks away from the ignition source thereby making it difficult to ignite a mattress.

Unlike institutional mattresses, comfort and aesthetics are of primary importance in the case of residential mattresses. In residential settings, therefore, fire performance must be achieved while still maintaining both comfort and aesthetics. For this reason, nonwoven,

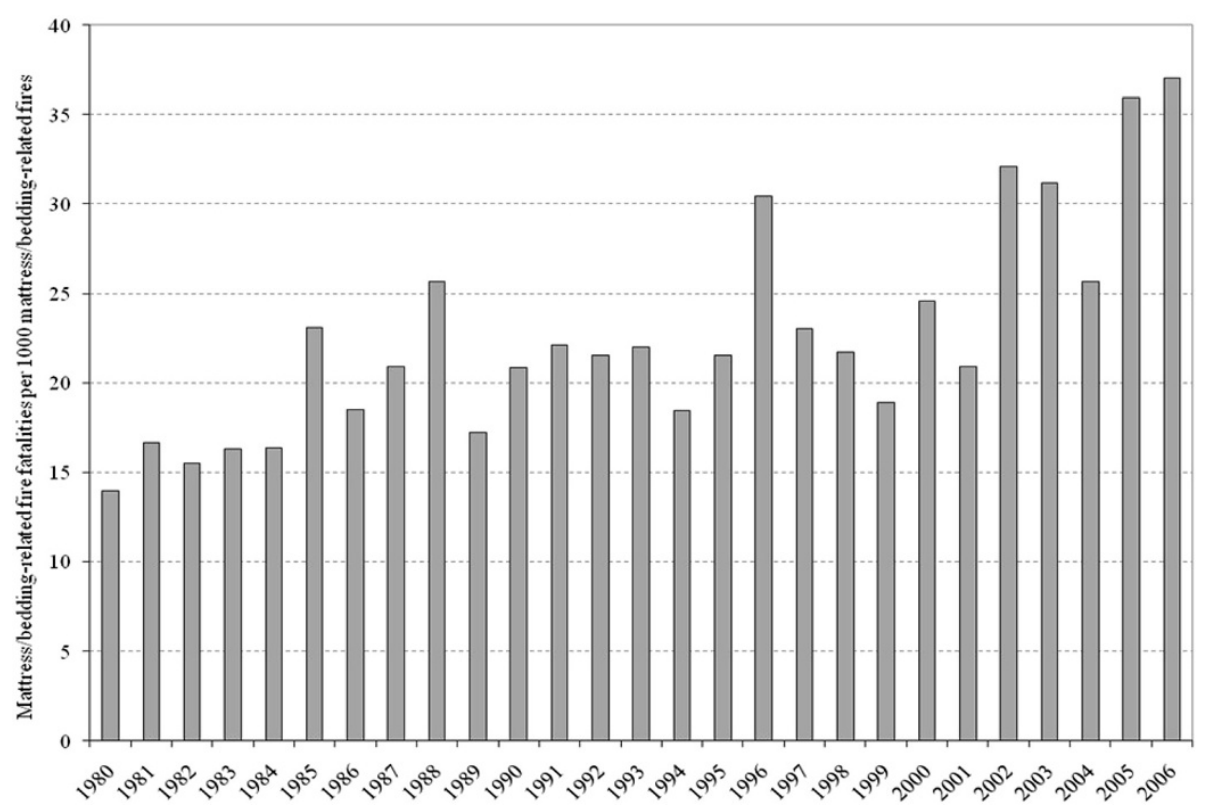

Figure 3 Mattress/bedding-related US residential fire losses from 1980 to 2006; civilian fatalities per 1000 mattress/bedding fires (for all ignition sources) (2007a). 
highloft battings are more commonly used as fire barriers in residential mattresses. Nonwoven cotton battings treated with boric acid have been used for many years as fire barriers in mattresses (Wakelyn et al. 2005). However, boric acid treatment may have problems associated with chalking, color change and undesirable texture (Toxicological Risks of Selected Flame Retardant Chemicals 2000). Highloft battings of FR rayon blended with polyester fibers have gained popularity especially after the introduction of 16 CFR 1633. These barrier materials are viewed as an environmentally friendly and economically practical approach to comply with 16 CFR 1633.

Another fire blocking technology uses core spun yarn to produce knitted barrier materials (2999c). In these designs, inherently fire resistant glass fiber forms the core, which is coated with a blend of char forming FR fiber and polyester fiber. Polyester fiber is primarily responsible for its aesthetic and comfort properties. The thermally stable core maintains the structural integrity during a fire by providing a woven framework (grid) for the char layer (lattice) formed by the thermal decomposition of the sheath fiber while burning. The composition of the core and sheath can be tailored to satisfy barrier performance and comfort requirements.

\section{Ticking}

Current residential mattresses use a wide range of tickings, including pile fabrics, knits, woven fabrics and jacquard designs. To address issues of physiological comfort, fire safety, and the growing incidence of allergies within the U.S. population, a variety of functional coatings, including water-proof, anti-bacterial, anti-fungal, and/or flame retardant finishes, are applied to the ticking of the mattress. The majority of modern ticking materials have a high polypropylene and/or polyester fiber count, with the fiber content varying significantly with the fabric structure and design pattern. While cotton, polyester and polypropylene fibers dominate the ticking industry, blends of luxury fibers, such as wool and silk, are becoming more prevalent. Renewable resources like corn, soybean and bamboo fibers are also gaining popularity as more environmentally friendly alternatives. Viscose rayon derived from bamboo is of particularly high interest because of its inherent antibacterial and anti-fungal properties and its good breathability and moisture absorption. However, very little is known about the flammability of these green alternatives.

For institutional mattresses, fire performance takes precedence over comfort and aesthetics. Polyvinyl chloride (PVC) tickings and fiberglass substrates with FR coatings are the preferred choices for institutional mattresses. A typical FR coating formulation consists of FRs (typically gas phase FRs), fillers, synergists and application ancillaries (e.g., polymeric resin binder, fabric softeners, and cross linking agents). A halogen-containing polymer, combined with vinyl chloride and finely dispersed antimony oxide is commonly used for coating ticking employed in heavy use applications such as healthcare mattresses.

\section{Factors influencing fire performance of mattresses}

The fire performance of a mattress depends on flammability of each of the components described in Section 4, along with the possible synergisms or antagonisms that may exist among them (Nurbakhsh \& Mc Cormack 1998).

In addition to mattress parameters, the fire performance of a mattress is significantly influenced by the type of test method, the size of the ignition source, and type of environment during fire testing.

In a full-scale mattress test, fire threat is often assessed based on PHRR and time-to-PHRR (TTP). Since the fire losses from a burning mattress depend not only on the size of the fire but also on how quickly it grows, the FIre Growth RAte (FIGRA) index (Sundström 2007; Nazare et al. 2002) could be a more appropriate indicator of fire performance. The fire growth rate index is calculated by dividing the peak heat release by time to peak heat release (FIGRA = PHRR/TPP), and can be used to estimate both the predicted fire spread rate and the fire hazard. The higher the FIGRA index value, the higher the fire hazard. Therefore, the FIGRA in reality becomes a heat acceleration parameter. However, care should be taken while predicting the fire threat of complete bedding assembly using FIGRA, since it has been shown that under certain conditions the HRR curves for these bedding assemblies show two distinct peaks (Ohlemiller \& Gann 2003). In such cases, the first peak is dominated by bedclothes with little contribution from the mattress and the second is dominated by the mattress and foundation.

\section{Mattress dimensions}

The construction and geometry of a mattress and foundation can be major factors affecting the fire performance of a mattress set. The fit of the foundation to the frame, the presence of the foundation and bedclothes all contribute to the fire hazard of a mattress.

\section{Mismatch between foundation and frame}

The presence or absence of the frame may affect the fire threat of a burning mattress. For example, a pool fire generated from flaming molten drips of burning bedclothes can result in rapid flame spread under the mattress, but this flame spread from under a mattress may not occur if the mattress set rests directly on the floor (Ohlemiller 2005).

The geometry of the foundation is especially important when the foundation is placed on a metal or a wooden frame. If the foundation does not fit precisely within the supporting frame, the small gap between the frame and the foundation offers a potential path for small flames on the foundation ticking to reach the underside of the 
Table 2 Scope of variations in mattress designs

\begin{tabular}{|c|c|c|}
\hline Mattress parameters & Description & Variations \\
\hline Height & Between $10.16 \mathrm{~cm}$ and $50.8 \mathrm{~cm}$ (4 in and $20 \mathrm{in})$ & \\
\hline Sizes & $\begin{array}{l}\text { Twin }(96.5 \mathrm{~cm} \times 187.9 \mathrm{~cm}(38 \mathrm{in} \times 74 \mathrm{in})) \text {, Full }(134.6 \mathrm{~cm} \times 187.9 \mathrm{~cm} \text { (53in x } 74 \mathrm{in})) \text {, Queen }(152.4 \mathrm{~cm} \times \\
203.2 \mathrm{~cm}(60 \mathrm{in} \times 80 \mathrm{in})) \text {, King }(193.0 \mathrm{~cm} \times 203.2 \mathrm{~cm}(76 \mathrm{in} \times 80 \mathrm{in})) \text { and California King }(182.8 \mathrm{~cm} \mathrm{x} \\
213.3 \mathrm{~cm}(72 \mathrm{in} \times 84 \mathrm{in}))\end{array}$ & 5 \\
\hline Construction & Single-sided and double-sided & 2 \\
\hline Mattress geometry & Smooth top, Tight top, Pillow top, Super pillow top, Euro top, Box pillow top. & 6 \\
\hline Mattress core & $\begin{array}{l}\text { Open coil with or without foam encasement, Pocket coil with or without foam encasement, Foam, } \\
\text { Viscoelastic, Latex, and Air }\end{array}$ & 8 \\
\hline Foundation geometry & $\begin{array}{l}\text { Steel/wood box continental }(22.8 \mathrm{~cm}(9 \mathrm{in})) \text { and } 7.6 \mathrm{~cm}(3 \mathrm{in})) \text {; Steel/wood Taped }(22.8 \mathrm{~cm}(9 \mathrm{in}) \text { and } \\
7.6 \mathrm{~cm}(3 \mathrm{in})) \text {; Wood box }(22.8 \mathrm{~cm}(9 \mathrm{in})) \text {; Wood box, cardboard taped }(5.0 \mathrm{~cm}(2 \mathrm{in})) ; \text { No box }\end{array}$ & 7 \\
\hline Upholstery/ fillings & Numerous combinations of fiber, fabric and foams & $\sim 100$ \\
\hline Ticking & Highly variable & $>1000$ \\
\hline \multicolumn{2}{|c|}{ Total variations excluding ticking variations: $5 \times 2 \times 6 \times 8 \times 7 \times 100=$} & $>336,000$ \\
\hline
\end{tabular}

* Bedclothes include a mattress pad, two bed sheets, a bed pillow with pillowcase and two blankets.

foundation (Ohlemiller 1995). If the underside of the foundation is not protected by fire barrier materials, the flames could then easily reach the more flammable materials used in mattress construction and the fire can result in flashover in a matter of a few minutes after ignition. To overcome this problem, the recent 16 CFR 1633 regulation specifies that the bed frame must match the dimensions of the mattress set. With double-sided mattresses, the burning of foundation may not adversely affect the overall fire performance of a mattress.

\section{Impact of mattress size}

Although the 16 CFR 1633 regulation does not specify mattress size, a twin size mattress is typically used in

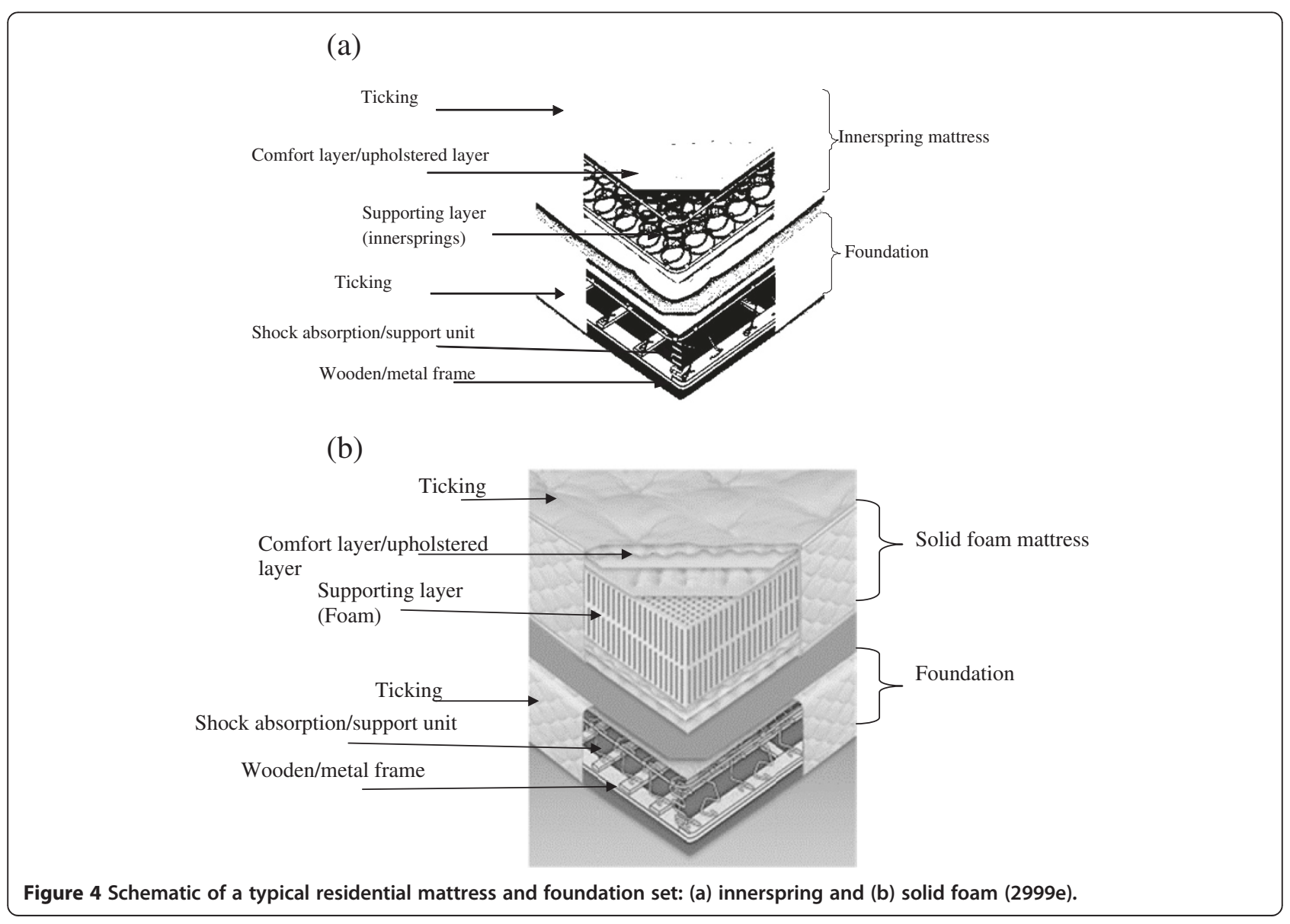


testing, since the fuel load and manufacturing cost are significantly less for a twin mattress than for a queen or king size mattress. Ohlemiller (Ohlemiller \& Gann 2002; Ohlemiller 2005) studied the dependence of PHRR on the size of a bedding assembly (mattress set with bedclothes). Heat release properties were measured using furniture calorimtery and test method described in 16 CFR 1633 (16 CFR 1633 2007). The mattress sets used in this study were standard innerspring mattresses with box spring foundations. The bedclothes consisted of a mattress pad (polyester/cotton batting), fitted and flat sheets (50:50 polyester: cotton), a blanket (100\% acrylic), a comforter and a pillow $(100 \%$ polyester fiberfill encased within a polyester/cotton shell) and a pillowcase (50:50 polyester:cotton). At $2293 \mathrm{~kW} \pm 25 \mathrm{~kW}$, the PHRR of a twin bed that contained standard PUF was $\sim 36 \%$ less than the PHRR of a king size bed of the same construction ( $3610 \mathrm{~kW} \pm 339 \mathrm{~kW}$ ) (set M-I in Figure 5). This increase in PHRR for the king size bed is less than a factor of two even though the surface area is twice as large for the king size bed (Ohlemiller 2005). Similar sized mattress sets constructed with a fire blocking barrier fabric (set M-II in Figure 5) reduced the PHRR by an order of magnitude. The PHRR of the king and twin size mattress sets (set M-II) were different within the standard uncertainty of the measurements. However, compared to set M-I where the PHRR for king size bed was significantly higher than the twin size bed, the values of PHRR for the king and twin mattress sets of M-II design were quite comparable. An FR modified mattress using a FR ticking (set M-III in Figure 5) was not as effective as one using a barrier fabric (set M-II) in reducing PHRR. This can be attributed to the failure of the FR ticking alone to protect underlying cushioning layers from burning. Neither FR modified mattress sets (M-II and M-III) showed a noticeable difference in PHRR between twin and king size beds. The study suggests that the size effect is only significant for standard PUF mattresses without any FR modification.

The inset in Figure 5 compares FIGRA index values (calculated using PHRR values from the first peak) for mattresses M-I, M-II and M-III. The FIGRA value of 10.87 for the king size bed reflects a greater fire hazard relative to the twin bed (FIGRA index of 5.50) with nonFR mattresses. For bedding assemblies with mattresses M-II and M-III, FIGRA values are very similar for twin and king sizes.

\section{Mattress construction}

\section{Interaction of the mattress and foundation}

It is possible for a foundation to improve the fire performance of a mattress set by reducing the air flow to the bottom of the mattress, thereby creating an oxygendeprived environment that can slow down fire growth or result in self-extinguishment. If the foundation is constructed with flammable materials, however, the additional fuel can contribute towards the heat release of the entire mattress set. Peak heat release rates for open flame testing of various mattresses with and without foundations are provided in Figure 6. All mattresses used to compare the fire performance of different foundations in this study (Damant \& Nurbakhsh 1992) used a similar innerspring construction with different PUF fillings. Based on their construction details and component attributes,

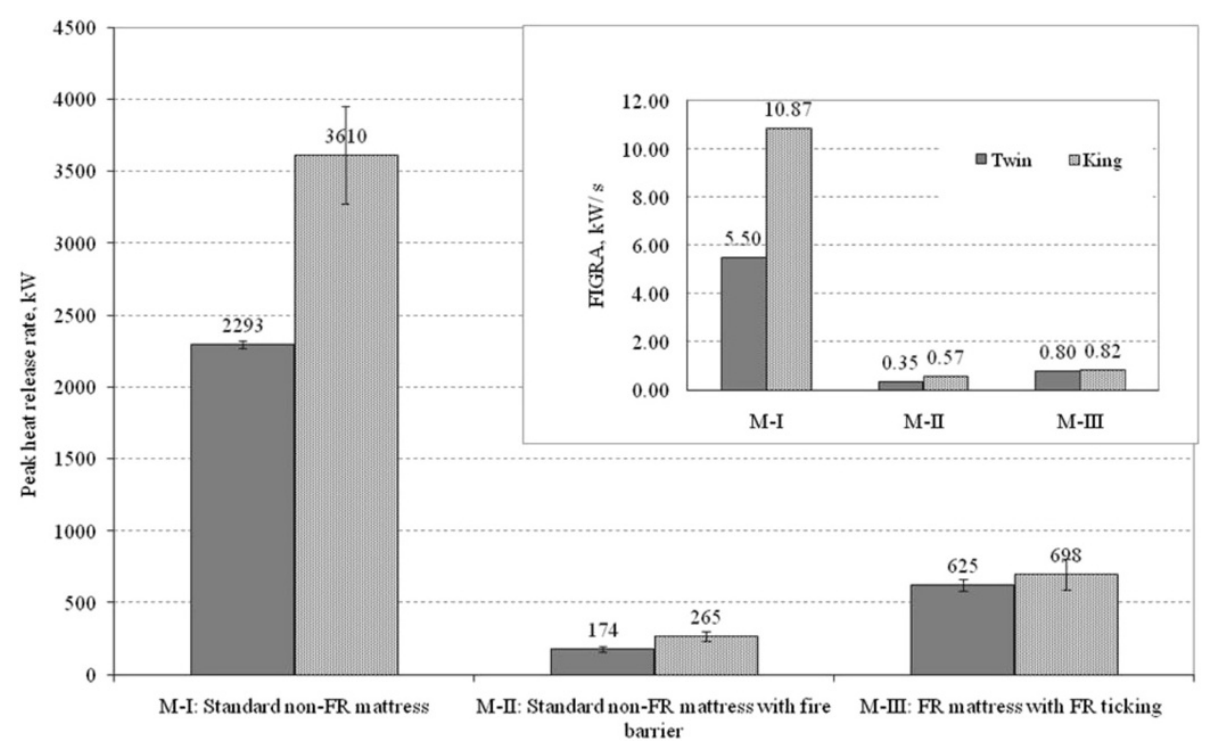

Figure 5 Impact of bed sizes on fire performance of (i) M-I Standard non-FR mattress, (ii) M-II Standard non-FR mattress with fire barrier and (iii) M-III FR mattress with FR ticking (Ohlemiller 2005). 


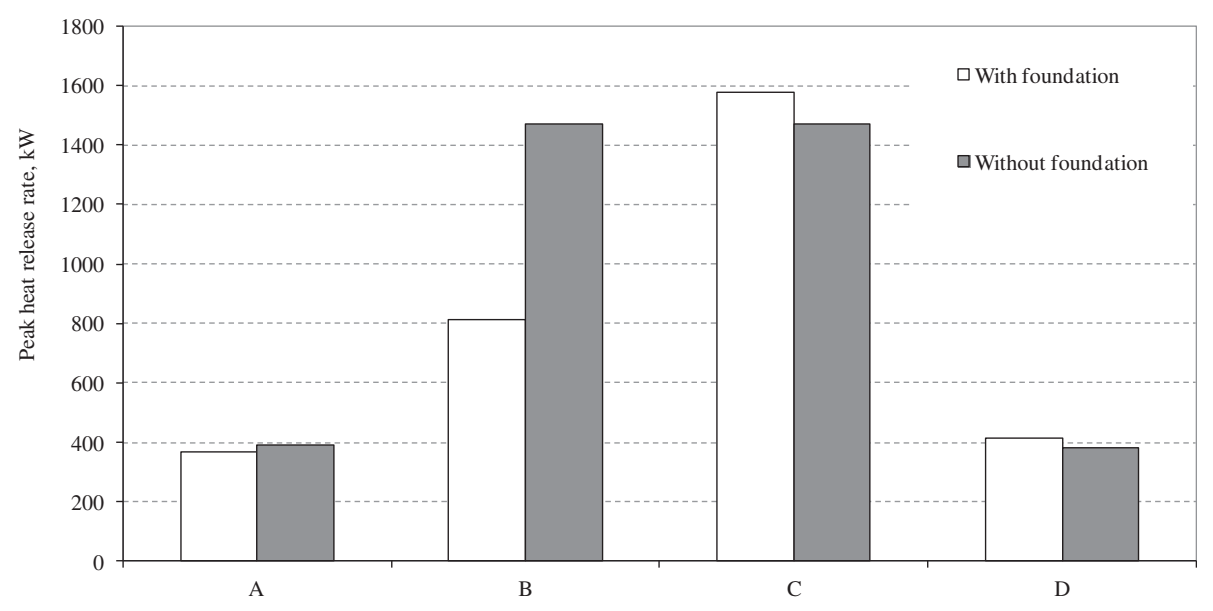

Figure 6 Impact of foundation on fire performance of mattresses (Damant \& Nurbakhsh 1992).

mattresses $\mathrm{A}$ and $\mathrm{D}$ are classified by the authors as low hazard mattresses, whereas mattresses $B$ and $C$ are classified as high fire threat mattresses. The presence of a standard metal and wood foundation with ticking had little impact on the PHRR of innerspring mattresses with conventional PUF filling (set A in Figure 6) or with Cal TB 117 grade FR-PUF filling (Technical Bulletin 117 2000) (set D in Figure 6). Adding a foundation containing a cotton batting resulted in a nearly $50 \%$ decrease in the PHRR for mattress set B compared to mattress B alone. With a PUF filler instead of a cotton batting in the foundation tested with mattress $C$ (similar component materials and construction to mattress B) the PHRR nearly doubled $(800 \mathrm{~kW}$ for set $\mathrm{B}$ and $1580 \mathrm{~kW}$ for set $C$ ). Unlike set $B$, the fire performance of mattress set $C$ is slightly worse than for mattress $C$ without the foundation.

Fires that begin in the foundation (foundation-forced fires) usually originate from the foundation side walls and eventually spread laterally onto the underside of the foundation top pad, with subsequent ignition of the wooden base (Ohlemiller 2005). The fire spread can ignite the mattress and can also aid in flame spread across the mattress or to other objects in the room. Many mattress fires resulting in flashovers have been attributed to foundation-forced fires. King size beds constructed by placing a king size mattress on top of two adjacent long twin-sized foundations generate an additional flammability concern stemming from the crevice between the two foundations under the longitudinal centerline of the mattress (Ohlemiller 2005). When a fire in the horizontal space between the mattress and the foundation reaches the vertical crevice between the two parts of the foundation, the flames spread inward into the vertical crevice over the full foundation height and move onto the bottom of the foundation. It has been speculated
(Ohlemiller 2005) that using a double-sided mattress may mitigate this fire hazard.

\section{Innerspring vs. solid core constructions}

Damant and Nurbakhsh (Damant \& Nurbakhsh 1992) reported on comprehensive full-scale fire tests conducted on both residential and institutional mattress constructions. Mattresses were tested according to the Cal TB 121 (Technical Bulletin 121 Flammability Test Procedure for Mattresses for Use in High Risk Occupancies) standard (Table 1), with the galvanized metal container with 10 double sheets of loosely wadded newspaper replaced by a T-shaped gas burner positioned parallel to the bottom horizontal surface of the mattress. Selected results and descriptions of mattress components and construction are given in Table 3. Comparative data for innerspring and solid foam core constructions with various filling components are graphically presented in Figure 7. Under similar testing conditions, the PHR of a solid foam core mattress with non-FR PUF is significantly greater than that of an innerspring mattress with similar filling material. Unless the PUF is FR modified, a solid core mattress is highly combustible. The recent Canadian study on residential twin sized mattresses concluded that solid core mattresses with non-FR PUF have potential of causing flashover (Bwalya et al. 2009). Mattresses with greater amounts of combustible materials have higher PHR and a higher FIGRA value (Table 4). However, the burning behavior of innerspring mattress filled with melamine type foam showed a significantly higher heat release $(453 \mathrm{~kW})$ than the solid core cellular foam mattress $(39 \mathrm{~kW})$ filled with similar melamine type foam. The higher PHR of the innerspring mattress filled with melamine type foam can be attributed to greater burning of the FR foam in a wellventilated innerspring type of mattress construction. Data in Table 3 indicates a higher mass loss of $9.842 \mathrm{~kg}$ for an 
Table 3 Heat release test data (as measured according to test method (open furniture calorimeter) described in Cal TB 129) for various mattress constructions (Damant \& Nurbakhsh 1992)

\begin{tabular}{|c|c|c|c|c|c|}
\hline \multicolumn{3}{|c|}{ Mattress description } & \multirow[t]{2}{*}{ PHRR (kW) } & \multirow[t]{2}{*}{ Ceiling temperature $\left({ }^{\circ} \mathrm{C}\right)$} & \multirow[t]{2}{*}{ Mass loss in $10 \mathrm{~min}(\mathrm{~kg})$} \\
\hline Type & Filling & Other & & & \\
\hline \multirow[t]{18}{*}{ Innerspring } & Conventional non-FR PUF & Without foundation & $337 \pm 57$ & $376 \pm 104$ & 8.300 \\
\hline & & With foundation & 366 & 375.5 & 9.389 \\
\hline & & With bedclothes* & 528 & 454 & 11.249 \\
\hline & $\begin{array}{l}\text { California TB } 117 \text { grade } \\
\text { FR PUF foam }\end{array}$ & Without foundation & $296 \pm 84$ & $277 \pm 61$ & 7.574 \\
\hline & & With foundation & 416 & 400 & 9.480 \\
\hline & $\begin{array}{l}\text { Highly filled melamine } \\
\text { type foam }\end{array}$ & - & $453 \pm 95$ & $458 \pm 59$ & 9.842 \\
\hline & Neoprene type foam & - & $48 \pm 28$ & 75.5 & 0.589 \\
\hline & Neoprene type foam & - & $50 \pm 24$ & 100.5 & 0.589 \\
\hline & $\begin{array}{l}2.54 \mathrm{~cm}(1 \mathrm{in}) \text { conventional } \\
\text { non-FR PUF pad Shredded } \\
\text { polyester fiber insulator pad }\end{array}$ & Reinforced vinyl cover & 335 & 282 & 4.762 \\
\hline & $\begin{array}{l}1.27 \mathrm{~cm} \mathrm{(} 1 / 2 \text { in ) conventional } \\
\text { non-FR PUF pad FR cotton } \\
\text { batting-boric acid treated } \\
\text { Shredded polyester fiber } \\
\text { insulator pad }\end{array}$ & Reinforced vinyl cover & 29 & 75.5 & 0.181 \\
\hline & $\begin{array}{l}\text { FR cotton batting-boric acid } \\
\text { treated Boric acid treated } \\
\text { insulator pad }\end{array}$ & Reinforced vinyl ticking & 17 & 69.4 & 0.090 \\
\hline & FR PUF foam & $\begin{array}{l}\text { Vinyl ticking, Topper pad of FR foam and } \\
\text { glass barrier }\end{array}$ & 65 & 123 & 1.723 \\
\hline & FR cotton batting & Woven ticking with aluminized barrier & 100 & 142 & 2.857 \\
\hline & FR cotton batting & Vinyl ticking & 71 & 127 & 2.086 \\
\hline & $\begin{array}{l}\text { FR cotton batting/ FR } \\
\text { insulator pad }\end{array}$ & $\begin{array}{l}\text { Non-woven FR barrier quilted to Cal } 117 \\
\text { foam and FR woven ticking, }\end{array}$ & 60 & 129 & 2.313 \\
\hline & $\begin{array}{l}\text { Fire barrier ( thin layer of } \\
\text { highly fire resistant cellular } \\
\text { foam bonded to fiberglass } \\
\text { fabric) }\end{array}$ & - & 22 & 63.3 & 0.226 \\
\hline & $\begin{array}{l}\text { Fire barrier ( highly engineered } \\
\text { fire resistant cover fabric) }\end{array}$ & - & 20 & 70 & 0.090 \\
\hline & Boric acid treated cotton filling & - & $22 \pm 1$ & 65.5 & $0.408 \pm 0.206$ \\
\hline
\end{tabular}


Table 3 Heat release test data (as measured according to test method (open furniture calorimeter) described in Cal TB 129) for various mattress constructions (Damant \& Nurbakhsh 1992) (Continued)

\begin{tabular}{|c|c|c|c|c|c|}
\hline \multirow[t]{6}{*}{ Solid core foam } & FR PUF foam & Vinyl ticking & 85 & 117 & 2.117 \\
\hline & $\begin{array}{l}\text { Highly filled melamine } \\
\text { type foam }\end{array}$ & Woven ticking & 62 & 134 & 1.587 \\
\hline & Boric acid treated cotton & - & 22 & 73.8 & 0.362 \\
\hline & Conventional non-FR PUF & - & 1716 & 1031 & 3.764 \\
\hline & California TB 117 grade FR PUF & - & 339 & 406 & 7.983 \\
\hline & $\begin{array}{l}\text { Highly filled melamine } \\
\text { type foam }\end{array}$ & - & 39 & 86.6 & 0.816 \\
\hline
\end{tabular}




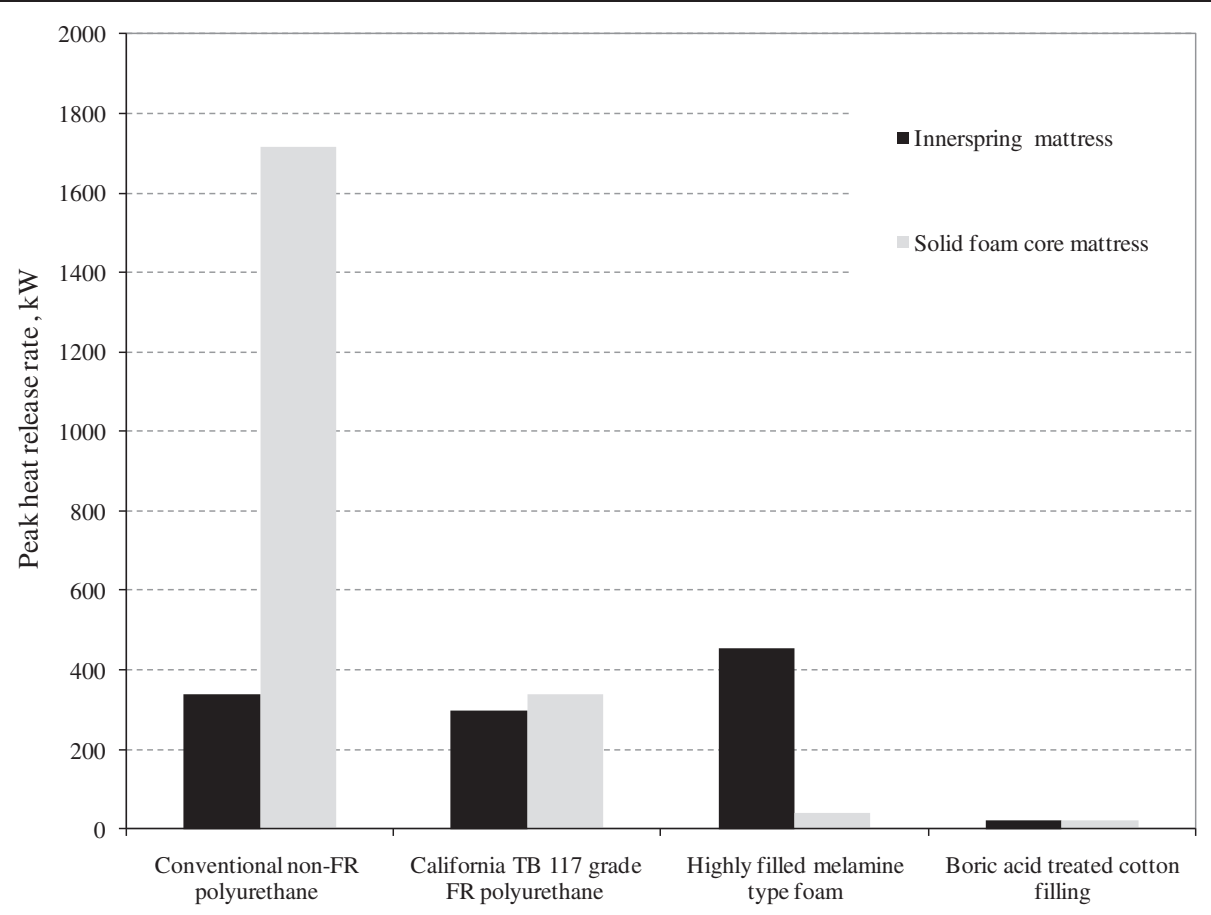

Figure 7 Impact of mattress construction on peak heat release rate: Innerspring vs solid core (Damant \& Nurbakhsh 1992).

innerspring mattress filled with the melamine type foam compared to a minimal mass loss of $0.816 \mathrm{~kg}$ for the solid core analog. Thus, the fuel load of a mattress may not by itself be used to predict its fire performance. Similar finding was also reported by Babrauskas (Babrauskas 1977). For mattresses incorporating Cal TB 117 grade foam (Technical Bulletin 117 2000) or boric acid treated cotton fillings in Figure 7, the type of construction (innerspring or solid core) had a minimal impact on peak heat release values.

\section{Type of foam}

As a part of large mattress hazard analysis program, Babrauskas (Babrauskas 1977; Babrauskas 1981) studied heat release properties of solid core foam mattresses. Composite samples with range of core foam and tickings were tested in cone calorimeter using oxygen consumption calorimetry. Test specimens were prepared by cutting samples from the full-size mattress. Heat release properties, smoke production, and FIGRA values for composite samples containing variety of foam are given in Table 5 . It can be noted from the Table 5 that when tested under incident heat flux of $50 \mathrm{~kW} / \mathrm{m}^{2}$, PUF and latex foam burn vigorously with PHRR of $1630 \mathrm{~kW} / \mathrm{m}^{2}$ and $1190 \mathrm{~kW} / \mathrm{m}^{2}$ respectively. With such flammability properties, the fullsize mattress made from standard PUF and latex foam resulted in room flashover in less than 10 mins. Depending on type of ticking material, polychloroprene foam has lower PHRR compared to PUF and latex foam. Polyvinly nitrile foam and hydrophilic PUF foam also had lower PHRR values. The average heats of combustion for different core materials can be ranked as: polypropylene > latex $>$ PUF $>$ polychloroprene $>$ polyvinylchloride $>$ PVC-

Table 4 Heat release data (as measured according to test method (open furniture calorimeter) described in 16 CFR 1633) for residential mattresses (Bwalya et al. 2009)

\begin{tabular}{|c|c|c|c|c|c|c|}
\hline Mattress construction & $\begin{array}{l}\text { Combustible } \\
\text { mass }(\mathrm{kg})\end{array}$ & PHRR (kW) & FIGRA (kW/s) & $\begin{array}{l}\text { Effective heat of } \\
\text { combustion (MJ/kg) }\end{array}$ & THR (MJ) & $\begin{array}{l}\text { Total smoke } \\
\text { released }\left(\mathrm{m}^{2}\right)\end{array}$ \\
\hline $\begin{array}{l}\text { Innerspring mattress with thick PUF } \\
\text { pillow top }-02\end{array}$ & 9.2 & 2038 & 8.78 & 24.9 & 232 & 42 \\
\hline $\begin{array}{l}\text { Innerspring mattress with thin PUF } \\
\text { pillow top }-03\end{array}$ & 5.3 & 1648 & 9.75 & 24.3 & 131 & 29 \\
\hline $\begin{array}{l}\text { Innerspring mattress with foam } \\
\text { encased pocket coils-06 }\end{array}$ & 10.5 & 3496 & 15.33 & 24.5 & 256 & 126 \\
\hline Solid core with three layers of PUF-01 & 12.5 & 3493 & 15.25 & 18.5 & 231 & 94 \\
\hline $\begin{array}{l}\text { Solid core mattress with viscoelastic } \\
\text { foam top-04 }\end{array}$ & 13.3 & 3433 & 12.57 & 22.5 & 300 & 132 \\
\hline
\end{tabular}


Table 5 Cone calorimtery data for composite specimen extracted from full-size solid core mattresses (Babrauskas 1981)

\begin{tabular}{|c|c|c|c|c|c|}
\hline & Ticking & Type of Solid core & PHRR at $50 \mathrm{~kW} / \mathrm{m}^{2}$ & FIGRA & Smoke parameter \\
\hline M01 & Polyvinlychloride & PUF /TDI & 1630 & 28 & 2.60 \\
\hline M04 & Polyvinlychloride with cotton backing & Latex (butadiene-styrene) & 1190 & 25 & 9.38 \\
\hline M05 & Rayon fabric & PUF & 960 & 27 & 0.33 \\
\hline M08 & Cotton fabric & Polychloroprene & 525 & 131 & 0.56 \\
\hline M09 & Polyvinlychloride with nylon fabric reinforcement & Polyurethane /TDI & 1050 & 27 & 1.19 \\
\hline M10 & Polyvinlychloride with nylon fabric reinforcement & Polychloroprene & 470 & 52 & 0.89 \\
\hline M11 & Cotton fabric & Polychloroprene & 386 & 129 & 0.23 \\
\hline M12 & Cotton fabric & Polychloroprene & 334 & 28 & 0.40 \\
\hline M13 & Cotton fabric & Polychloroprene & 519 & 216 & 0.76 \\
\hline M14 & Polyvinlychloride & Polyvinlychloride & 585 & 4 & 1.93 \\
\hline M15 & Polyvinlychloride with nylon fabric reinforcement & Hydrophilic PUF & 198 & 40 & \\
\hline M16 & Cotton fabric & PUF & 658 & 7 & 1.31 \\
\hline M18 & Cotton fabric & PUF & 728 & 73 & 0.05 \\
\hline M20 & Polyvinlychloride & PUF & 950 & 26 & 1.97 \\
\hline M22 & Polyvinlychloride with nylon fabric reinforcement & Hydrophilic PUF & 224 & 8 & 0.70 \\
\hline M23 & Polyvinlychloride & PVC Nitrile & 554 & 35 & 4.46 \\
\hline M24 & Fiberglass coated with polyvinlychloride & PVC Nitrile & 313 & 12 & 0.82 \\
\hline M25 & Polyvinlychloride with nylon fabric reinforcement & Hydrophilic PUF & 168 & 6 & 0.20 \\
\hline
\end{tabular}

nitrile $>$ hydrophilic PUF. The smoke production tendencies of these materials can be ranked as latex $>$ PVC-nitrile $>$ PUF $>$ polyvinylchloride $>$ polychloroprene $>$ hydrophilic PUF.

FIGRA values for polychloroprene specimen in Table 5 are significantly higher compared to high PHRR specimens. This is probably because the PHRR occurs much earlier during burning of the specimen giving high FIGRA value.

\section{Ticking}

The direct contribution of the ticking to the fire threat is considered to be low because the heat release potential of the ticking is small compared to the mattress. In residential mattresses, ticking is considered as a sacrificial layer, which means it burns quickly and release very little heat. The rapid burning of ticking prevents the flames from staying in any one area sufficiently long to ignite the underlying components of the mattress. The sacrificial concept of ticking implies use of very low weight fabric tickings. However, modern residential mattresses include a variety of material layers into a quilted assembly which forms a top cover. Such composite ticking materials, in addition to arrangement of underlying fire blocking layers, have the potential to alter heat release properties of mattresses. Full-scale open flame testing of residential mattresses with composite tickings have shown that a change in the ticking alone has significantly increased the heat release rate of mattresses by more than $200 \%$ in some cases (2007c).
In 16 CFR 1632, tickings are classified according to their smoldering performance. The code also defines the criteria for retesting the fire performance of the mattress set when the ticking is changed (16 CFR 1632.6). As long as the ticking is replaced with a ticking of the same classification and nothing else is changed, then retesting the compliance of the mattress set is not required. A more detailed description of ticking classifications is provided in Table 6. Unlike 16 CFR 1632, 16 CFR 1633 does not define a ticking classification and does not require retesting to determine the open flame performance of a mattress set if only the ticking has been changed. This is primarily because the ticking was not found to significantly affect the open flame performance of mattresses tested at NIST (Ohlemiller \& Gann 2002; Ohlemiller \& Gann 2003). However, since the adoption of the regulation, vendor data ( 2007c) has shown a significant increase in PHRR and THR of mattress sets (even to the extent of being non-compliant) in cases where only the ticking has been changed. This suggests that the ticking may not be sacrificial in these cases. The original experiments conducted at NIST (Ohlemiller \& Gann 2002; Ohlemiller \& Gann 2003), which were used by CPSC to develop 16 CFR 1633, involved only a few ticking types and constructions that represented the majority of the market at that time.

The impact of tickings with different fiber content and fabric finishes on the fire performance of mattresses has been studied ( 2007c) using the test procedure described in 16 CFR 1633. The results from this study are summarized in Table 7. All tested residential mattresses had a similar innerspring construction except for the 
Table 6 Classification of ticking according to 1632.6 of 16 CFR 1632 (16 CFR 1632 Standard for the flammability of mattresses and mattress pads 1991)

\title{
Test procedure
}

\author{
Performance requirements
}

Ticking characteristics

Substitution procedure

\begin{tabular}{|c|c|c|c|c|}
\hline Class A & $\begin{array}{l}\text { Three ticking prototypes tested directly over cotton } \\
\text { batting on the test boxes and Three ticking prototypes } \\
\text { tested over urethane foam covering the cotton batting } \\
\text { on the test boxes }\end{array}$ & $\begin{array}{l}\text { All six specimens meet the test criteria } \\
\text { (char length }<2.54 \mathrm{~cm}(1 \mathrm{in}) \text {, cotton } \\
\text { batting does not ignite). }\end{array}$ & $\begin{array}{l}\text { Acts as barrier against } \\
\text { cigarette ignition. }\end{array}$ & $\begin{array}{l}\text { May be used on any qualified } \\
\text { mattress prototype without conducting } \\
\text { new prototype test. }\end{array}$ \\
\hline Class B & $\begin{array}{l}\text { Three ticking prototypes tested over PUF covering the } \\
\text { cotton batting on the test boxes }\end{array}$ & $\begin{array}{l}\text { The three specimens tested over PUF } \\
\text { meet the test criteria. One or more } \\
\text { specimens tested over cotton batting } \\
\text { do not meet the test criteria. }\end{array}$ & $\begin{array}{l}\text { Has no effect on cigarette } \\
\text { ignition. }\end{array}$ & $\begin{array}{l}\text { May be used on any mattress prototype } \\
\text { which was qualified with Class B or Class C } \\
\text { without conducting new prototype tests. }\end{array}$ \\
\hline Class C & $\begin{array}{l}\text { Three ticking prototypes tested over urethane foam } \\
\text { covering the cotton batting on the test boxes }\end{array}$ & $\begin{array}{l}\text { One or more specimens tested over PUF } \\
\text { covering cotton batting do not meet } \\
\text { the test criteria. }\end{array}$ & $\begin{array}{l}\text { Has the potential to act as a contributor } \\
\text { to cigarette ignition. }\end{array}$ & $\begin{array}{l}\text { Requires a new mattress prototype test before } \\
\text { the ticking fabric is used in mattress production. }\end{array}$ \\
\hline
\end{tabular}


Table 7 Heat release test data (as measured according to test method (open furniture calorimeter) described in 16 CFR 1633) for mattresses with different tickings (2007c)

\begin{tabular}{lllcccc}
\hline Tick ID & Fabric content (mole fraction \%) & Finish & PHRR (kW) & TTP* $^{*}(\mathbf{s})$ & THR in first 10 mins (MJ) & FIGRA ${ }^{* *}$ (kW/s) \\
\hline T-1 & Polypropylene (100)a & Pigment print & 73 & 900 & 12.7 & 0.08 \\
\hline T-2 & Polypropylene/Polyester (50/50) & Heat set softener & 76 & 1380 & 13.3 & 0.05 \\
\hline T-3 & Polypropylene/Polyester (32/68) & Hot melt & 32 & 60 & 3.9 & 0.53 \\
\hline T-4 & Polyester (100) & Aqueous scour & 38 & 60 & 14.7 & 0.63 \\
\hline T-5 & Polyester (100) & Latex & 49 & 60 & 5.4 & 0.81 \\
\hline T-6 & Cotton/Polyester (75/25) & Bleach & 31 & 60 & 6.8 & 0.51 \\
\hline T-7 & Rayon/Polyester (54/46) & none & 31 & 102 & & 0.30 \\
\hline
\end{tabular}

* TTP: Time to peak heat release rate, ${ }^{* *}$ FIGRA: Fire growth rate index.

tickings. Heat release test data for mattresses with different tickings is given in Table 7. T-1 and T-2 samples have a THR of 12.7 MJ and 13.3 MJ, respectively, which are within $20 \%$ of the $15 \mathrm{MJ}$ THR failure criteria in 16 CFR 1633. However, these specimens have very low FIGRA values (0.08 and 0.06 respectively), which suggests that the estimated fire spread and size of the resulting fires may be significantly lower than for the specimens with lower THR values (T-3, T-4 and T-6 and T-7). Data in Table 7 suggest that changing the ticking component significantly alters the fire performance of the mattress. Previous studies (Horrocks et al. 2001) have also shown that PHRR values might be dependent upon the fabric surface and fabric construction of the tickings in addition to their fiber content and fabric finish.

Study (Fritz \& Hunsberger 1997) on the flammability testing of mattress composites have shown that the quilting also affects burning behavior, such that quilted specimens exhibit slightly higher THR values as compared to non-quilted specimens when tested under the cone calorimeter. One of the probable reasons for this kind of fire performance may be attributed to the fact that flame spread in quilted specimens is much slower. Quilting prevents rapid flame propagation and hence the material burns slowly but completely to give higher THR values.

\section{Interaction with fire barrier materials}

Tickings perform differently in the presence or absence of fire barrier materials. A large majority (about $80 \%$ ) of mattresses with a polyvinyl chloride (PVC) ticking pass the high occupancy dwelling open flame test (TB 129) without using a fire barrier material, because PVC tickings are active fire barriers that self extinguish. Approximately $20 \%$ of the mattresses with PVC coated tickings fail due to antagonistic reactions of the highly plasticized PVC coated fabrics with other components of upholstery. Mattresses with cotton/fiberglass tickings also do not require an additional barrier fabric layer to protect the underlying cushioning layer. In this case, the cotton/ fiberglass ticking acts as a passive fire barrier that physically prevents flame and heat transfer to the underlying cushioning layer. On the other hand, thermoplastic tickings used in modern residential mattresses do require a fire barrier in order to pass the open flame test. A study (Nurbakhsh \& Mc Cormack 1998) that investigated the effects of cover fabrics and filling materials with and without fire barriers showed that polyester and polyester blend ticking perform poorly in the presence of a barrier material. Furthermore, placement of the barrier in the mattress can be critical to the resulting fire performance. The role of barrier materials is discussed in much greater detail in the following section.

\section{Fire barrier materials}

\section{Innerspring mattresses}

The impact of fire barriers on the fire performance of innerspring mattresses with the same construction but different filling materials is shown in Figure 8. With a fire barrier (fibreglass fabric), these innerspring mattresses were able to pass with $100 \%$ success the high occupancy dwelling, open flame ignition test for mattresses (Cal TB 129), regardless of the filling type (e.g., standard PUF, polyester fiber batting/PUF, or a cotton batting/ felt) (Technical Bulletin 129 1992). Without the fire barrier fabric, the TB 129 performance of the mattresses was inconsistent, with the degree of failure depending on the type of filling material. For example, PUF innerspring mattresses had a success rate of 44\%, signifying four passes out of 10 tests. The cotton batting/ PUF and polyester fiber batting/cotton felt/PUF innerspring mattresses yielded a success rate two times greater at approximately $88 \%$. Innerspring mattresses with a polyester fiber batting combined with an insulator pad and PUF or cotton batting had a 100\% TB 129 success rate without the need for a fire barrier fabric.

\section{Solid core mattresses}

In this same study, the researchers determined that solid core PUF mattresses passed TB 129 without using a fire barrier fabric. This is presumably a result of the 


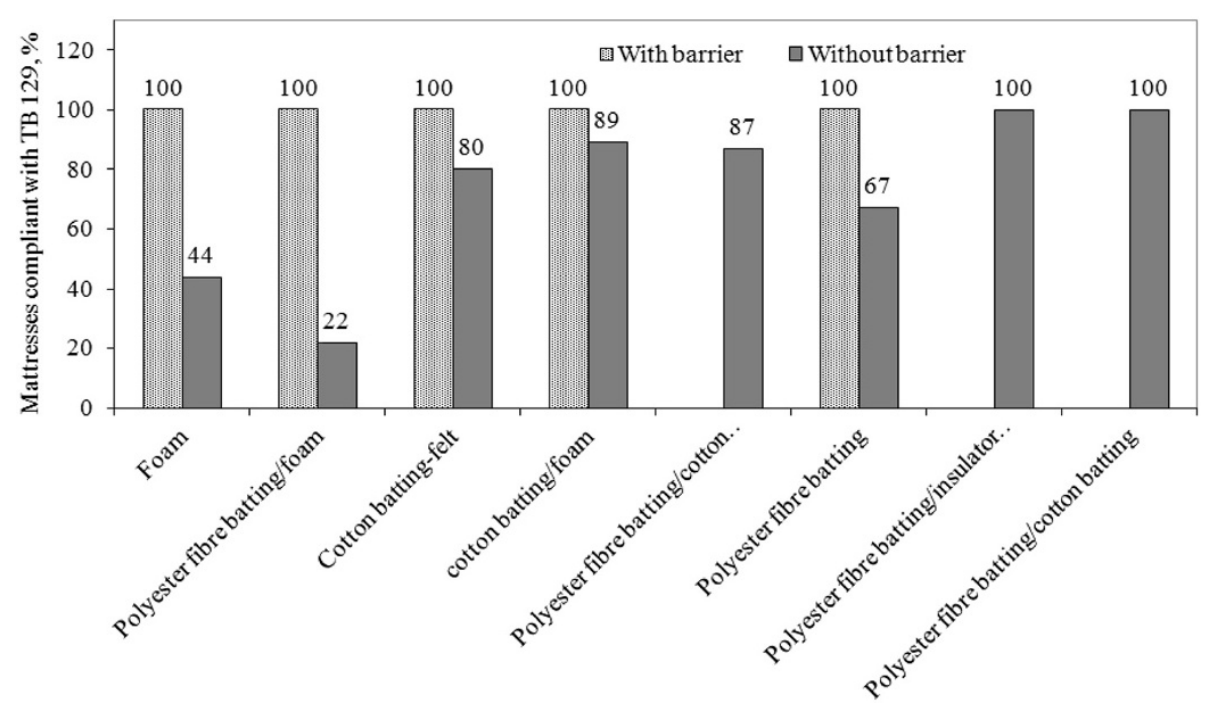

Figure 8 Comparison of innerspring mattresses with different type of filling materials in presence or absence of barrier fabrics (Nurbakhsh \& Mc Cormack 1998).

restricted airflow in a solid core mattress, which restricts the entrainment of oxygen needed to sustain pyrolysis. This suggests that under the right construction and with the favorable combination of materials it may be possible to pass TB 129 without using a fire barrier fabric. Furthermore, study by Breese (Breese 1977) suggested that while the fire barriers (glass fiber fabric) served to reduce flaming combustion hazard by reducing heat release rate of solid core neoprene mattress, they permitted more heat buildup in the cores and induced smoldering which eventually consumed the mattress. They also pointed out that glass/ceramic fire barrier of thickness up to $44 \mathrm{~mm}$ is required to reduce the flaming hazard. Use of such fire barriers may not be comfortable, attractive, or cost-effective and hence not recommended.

\section{Institutional vs. residential mattresses}

The materials and constructions discussed above for passing TB 129 are generally used for institutional mattresses. Ticking with polyester or polyester blends that are used in many residential mattresses behave very differently in the presence of fire barriers. Moreover, the test methods employed for mattresses used in public occupancies (Cal TB 129) and residential mattresses (16 CFR 1633) use different ignition sources thus the thermal insult seen by tickings in such mattresses would be significantly different. The Cal TB 129 uses single propane gas burner which is applied to the mattress side whereas 16 CFR 1633 uses dual burner (also known as NIST burner) to apply flaming ignition to both the side and top surfaces of the mattress. The NIST burner replicates burning bedclothes on mattress and mimics pool fire caused by melting of bedclothes. The effects of melting and dripping can have a varied impact on the flammability of a mattress. Fire barriers often fail to protect the underlying material when melting and shrinkage occur. This can cause tensile stresses to develop within the barrier material, resulting in breakage that allows flame and heat to penetrate. This particular failure mechanism is a major concern for barriers based on charring organic fibers.

Compliance data for residential mattresses with highloft or other newly engineered fire barriers are currently not available. Several polyester blend tickings are being currently investigated and their fire performance with and without fire barrier materials is being studied in our Fire Research Division (FRD).

\section{Bedclothes}

Several statistical studies ( 2999d; 2002b) have shown that most residential mattress fires are started by burning bedclothes. In addition to mattresses, burning bedclothes have potential to ignite other combustible items in a bed room such as curtains, drapes, carpet and other items of furniture. The size and type of fire from burning bedclothes may depend upon many factors, including the amount of mass of bedclothes, the physical configuration of bedclothes over a mattress, and most importantly the kind of ignition source to which they are subjected (Flammability 2999). Once ignited, properly arranged bedclothes and especially the pillow, acts as a continued source of ignition []. Depending on the type of mattress used in the test, woolen blankets demonstrated reduced fire intensities, while acrylic, cotton and polypropylene blankets burned with greater intensities (Woolley 1976). 
Over the last 20 years there have been two sets of detailed studies by Damant and Nurbakhsh (Damant \& Nurbakhsh 1992) and Ohlemiller (Ohlemiller \& Gann 2003) that demonstrate that burning bedclothes on a mattress have the potential to bring a room to flashover. Since both studies were performed before 2007, their conclusions were based on experiments conducted on mattresses that were not compliant with 16 CFR 1633. In three different scenarios using mattresses/foundation sets with and without bedclothes, Damant (Damant \& Nurbakhsh 1992) reported that the presence of bedclothes (including a mattress pad, two bed sheets, a bed pillow with pillowcase, and two blankets) caused a $10 \%$ to $30 \%$ increase in the PHRR (Figure 9). In order to determine the specific contribution of bedclothes towards the fire performance of the bedding assembly with different mattress construction and uniform set of bedclothes, the heat release test data for mattresses was normalized by subtracting the heat release data of bedclothes alone. The flammability data for bedclothes was determined by burning the bedclothes assembly on an "inert" mattress made of fiberglass is shown in Figure 10. The bedclothes on the inert surface (black bar) were reported to generate PHRR of $146 \mathrm{~kW}$, mass loss at $10 \mathrm{~min}$ of $2.4 \mathrm{~kg}$, and ceiling temperature of $200{ }^{\circ} \mathrm{C}$. The mattress constructions (Table 8) for the twin beds in this study were primarily innerspring (M1, M2, M4, M5, M6, and M7) or solid core foam (M3 and M8) with varying cushioning components, such as containing a FR cotton batting (M1, M2, M4 and M5) or FR-PUF (M3, M6, M7 and M8).
Mattresses with vinyl ticking (M2, M6, M7 and M8) were primarily institutional mattresses whereas M1, M3, M4 and M5 were residential mattresses.

In Figure 10, the greatest fire threat is posed by the M7 construction with bedclothes; with PHRR (200 kW) nearly twice the reported values for all other bedding assemblies. Negative values of "normalized" data for bedding assemblies in Figure 10, which are the bedclothes values subtracted from the combination mattress and bedclothes values, indicates that in most cases the bedclothes alone pose a greater fire threat than the mattress combined with bedclothes. Only in case of Mattress M7 does the normalized data have positive value suggesting greater fire hazard of the mattress itself. Constructions M2, M3, M4, and M6 may pose the lowest fire threat, as these mattresses generate the lowest reported values for PHRR. Bedding assemblies with these mattresses however yielded more $\mathrm{CO}$ (values not reported here) during burning suggesting more incomplete combustion. The above study suggests that the PHRR for bedclothes alone is greater than mattress itself in most combinations.

In an attempt to explore potential methods of improving fire performance of bedclothes, in 2003, Ohlemiller (Ohlemiller \& Gann 2003) reported on the impact of normal and FR bedclothes on the heat release rates of standard and FR modified mattress sets. Normal bedclothes included filled items consisting of a mattress pad, a comforter and a pillow with polyester (100\%) fiberfill, in addition to two sheets, a blanket and a pillowcase. The sets of FR modified

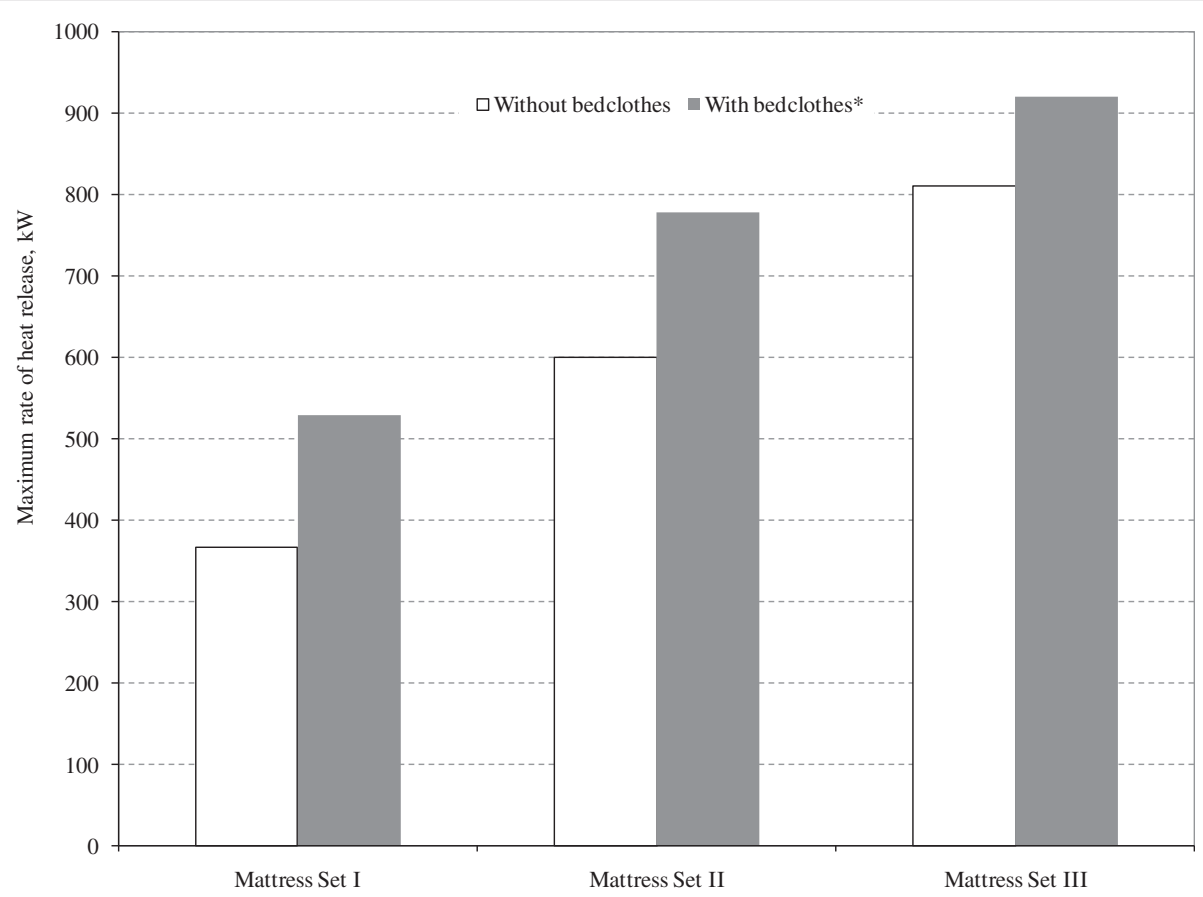

Figure 9 Impact of bedclothes on fire performance of various mattress/foundation sets. (Damant \& Nurbakhsh 1992) *Bedclothes include a mattress pad, two bed sheets, pillow with a pillowcase, and two blankets. 


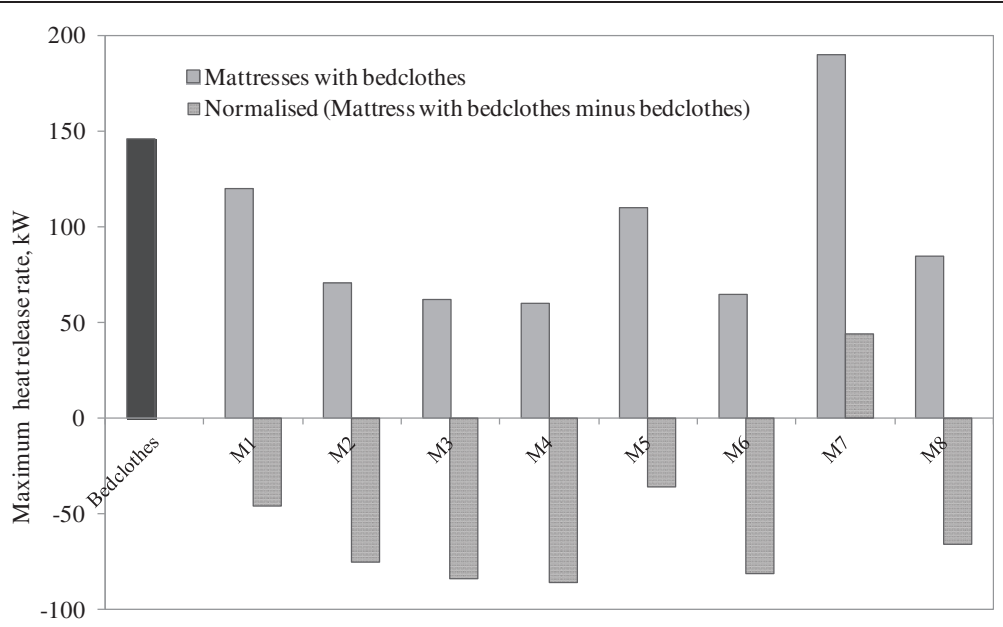

Figure $10 \mathrm{Impact}$ of normal bedclothes on fire performance of mattresses having varying levels of fire retardance (Damant \& Nurbakhsh 1992).

bedclothes were of two types: i) mattress pad, comforter and pillows with FR fiberfill and ii) mattress pad, comforter and pillows with FR barriers under their respective cover shells. Complete bedding assembly was tested under an open hood and oxygen consumption calorimetry was used to measure heat release rates. Each fire was initiated by a $30 \mathrm{~s}$ application of a small butane flame applied to the vertically hanging covers. The FIGRA values derived from Ohlemiller's data are plotted in Figure 11 and Figure 12. Figure 11 compares the impact of mattress pad modifications on fire performance of standard PUF as well as FR modified mattresses. In this experiment 4 mattress pads with different fiberfill were used in presence and absence of a protective skirt. The details of the mattress pads are given in Table 9. The FIGRA was generally around 10 times higher for the standard PUF mattresses as compared to the FR modified mattresses. This is in agreement with previous findings (Palmer et al. 1975) where the involvement of the additional fuel was seen to depend strongly on the type of mattress used. For the bedding assemblies where the mattress pad includes a protective skirt, the FIGRA values were more comparable (Figure 11). The protective skirt, which is essentially an extra layer of protection, significantly improves the fire performance of bedding assembly. The study also suggested that layers are more effective than FR fillers. Mattress pad A with charring and non charring (thermoplastic) fiberfill in Figure 11 shows the most antagonistic effect on a PUF mattress; that is, it worsens the flammability behavior of the bedding assembly. This may be due to the 'scaffolding effect' of charring and non charring blends, in which the melting thermoplastic envelops the surface of the charring fibers and this developing carbonaceous char prevents any shrinkage of the blended component away from an approaching flame or igniting source (Gawande Nazaré 2002).

Figure 12 compares the fire threat of FR modified mattresses with a full set of normal and FR modified bedclothes. Detailed description of FR modified mattresses and bedclothes used in this study are given in Table 10 . Again, it was noted that the use of a protective skirt further enhances the flame retardance of the bedding assembly in FR modified mattresses.

Table 8 Details of mattress construction and components (Damant \& Nurbakhsh 1992)

\begin{tabular}{lllll}
\hline Mattress ID & Construction type & Filling & Ticking & Application \\
\hline M1 & Innerspring & FR cotton batting & Woven ticking with aluminized barrier & Residential \\
\hline M2 & Innerspring & FR cotton batting & Vinyl & Institutional \\
\hline M3 & Solid foam & FR polyurethane (melamine foam) & Woven fabric & Residential \\
\hline M4 & Innerspring & FR cotton batting + insulator pad & $\begin{array}{l}\text { FR Woven fabric, Non-woven barrier } \\
\text { quilted to Cal 117 foam and ticking }\end{array}$ & Residential \\
\hline M5 & Innerspring & FR cotton batting + insulator pad & Woven ticking quilted to Cal 117 foam & Residential \\
\hline M6 & Innerspring & FR polyurethane foam/Topper pad & Vinyl & Institutional \\
\hline M7 & Innerspring & FR polyurethane CMHR foam & Vinyl & Institutional \\
\hline M8 & Solid foam & FR polyurethane foam & Vinyl & Institutional \\
\hline
\end{tabular}




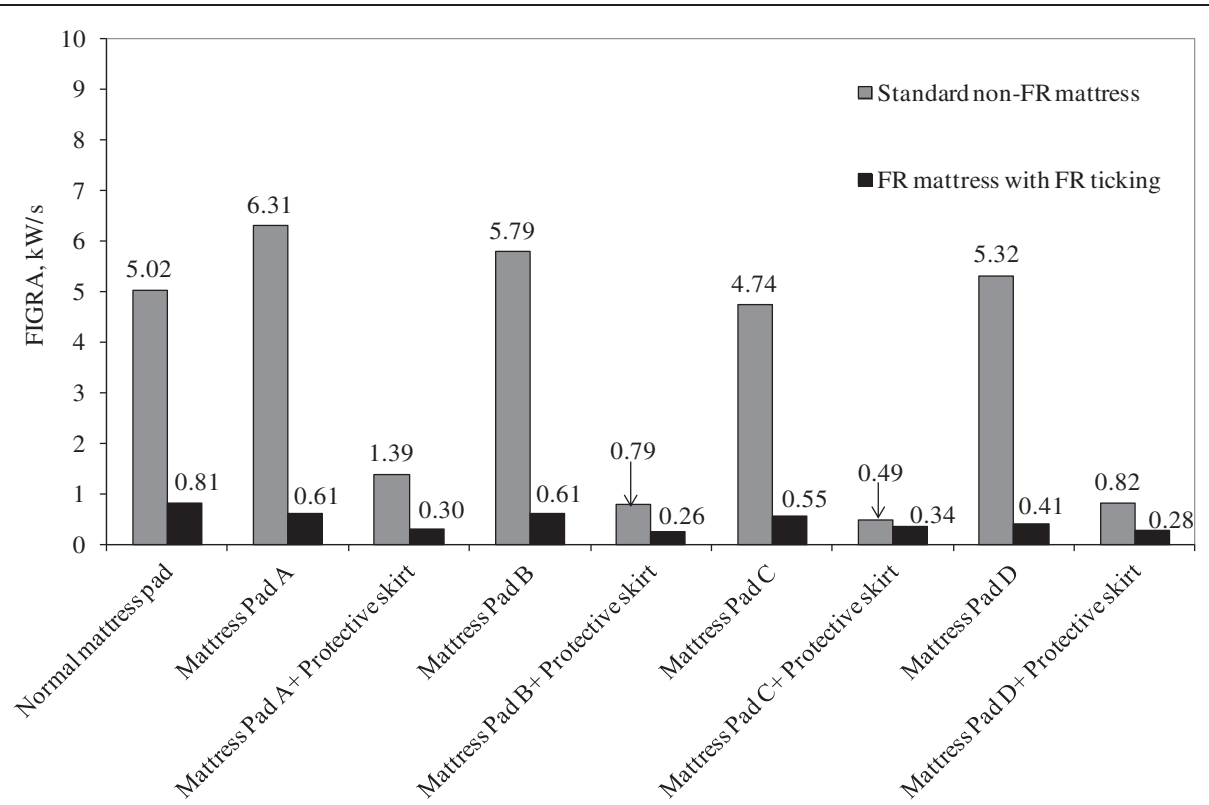

Figure 11 Impact of mattress pads on fire performance of FR and non-FR mattresses (Ohlemiller \& Gann 2003).

Olhemiller study (Ohlemiller \& Gann 2003) demonstrated that fire barriers are more efficient in improving fire performance of bedclothes as opposed to using FR fillers. To date, FR bedclothes do not have any significant usage in any occupancy. However, the fire community may need to consider the impact bedclothes have on fire losses and fire performance criteria in current or proposed mattress regulations.

\section{Test environment}

Previous studies (Babrauskas 1977) on effects of ventilation on flammability of institutional mattresses have shown that restricted ventilation within a given compartment lowers the PHRR but not the time-to-PHRR. As expected, increased carbon monoxide levels were also recorded. The two types of environment used in fire testing, open hood and room, may result in very different fire behaviors (Sundström 2007; Ohlemiller 1995). In a systematic study on effects of room environment on fire performance of furniture, CBUF report shows wide disparity between furniture calorimeter and room calorimeter results for propagating mattress fires (Sundström 2007). More flammable mattresses experience major radiative augmentation from the room resulting in rapid fire growth. Ohlemiller (Ohlemiller 1995) studied fire tests in both environments using NIST furniture calorimeter (oxygen

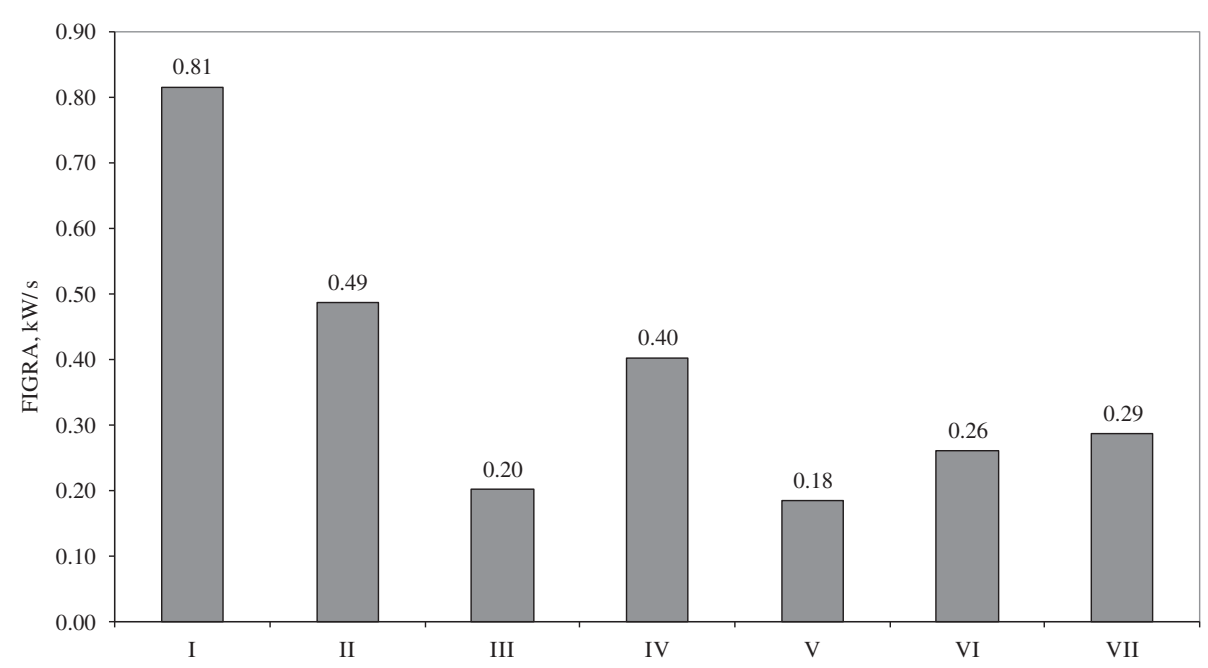

Figure 12 Impact of bedclothes on fire performance of FR modified mattresses. (Ohlemiller \& Gann 2003). 
Table 9 Description of mattress pads and fiberfill (Ohlemiller \& Gann 2003)

\begin{tabular}{llll}
\hline Mattress pad description & Top shell & Fiberfill & Bottom shell \\
\hline Normal mattress pad & $100 \%$ cotton & $100 \%$ polyester & Non-woven scrim \\
Mattress pad A & & Blend of charring/non-charring fibers \\
Mattress pad B & & Charring fiber \\
Mattress pad C & $100 \%$ polyester charring barrier fabric (Type I) \\
Mattress pad D & & $100 \%$ polyester charring barrier fabric (Type II) & \\
\hline
\end{tabular}

consumption-based calorimeter similar to the system described in ASTM 1590 (ASTM E1590-12 2999)) and identified two mechanisms by which a room environment could affect the burning behavior of a mattress: through thermal feedback from the smoke layer to the burning surfaces and through oxygen limitation, which depends on the openings in the room and their effect on ventilation. This susceptibility to room effects makes it difficult to achieve inter-laboratory agreement on data and on the evaluation of the fire hazard for mattresses of similar construction. However, to avoid such a discrepancy in compliance testing of mattresses, the test criteria for the 16 CFR 1633 is relatively severe with PHRR of $>200 \mathrm{~kW}$ is an immediate test failure resulting in test termination.

\section{Conclusions}

Variations in mattresses size, geometry, construction type, and component materials are major factors in determining the fire threat of a mattress. Test apparatus and test environment can also influence flammability of a mattress. The size effect is only significant for standard mattresses without any FR modification. The soft components of a mattress are manufacturer-dependent, with several highly engineered combinations of fibers, fabrics and foams available. All these factors impact flammability of a mattress individually and collectively. In order to allow the mattress manufacturer sufficient flexibility to satisfy the comfort and aesthetic needs of the consumer while still complying with the stringent flammability standards, fire blocking materials appear to be a promising solution.

A fire barrier is part of the overall mattress system. Formulation or physical changes to other components in the system may affect the fire performance of a selected barrier system. As discussed in this report, studies on the impact of fire barriers on the fire performance of mattresses have shown that the performance of fire barriers is strongly dependent on the type of ticking, especially when a flame is used as an ignition source. When used with incompatible combinations of filling materials and tickings, fire barriers may fail to prevent a rise in temperature, smoke and carbon monoxide formation. To date no guidelines exist for the usage of fire barriers in mattress construction. Guidelines for quantifying the performance of fire barriers are also lacking. Currently, the work at NIST is focused on identifying measurement science tools for quantifying the performance of fire barrier materials and for developing materials that may be used to generate a superior fire barrier. Furthermore, it is important to develop bench-scale composite test that is simple, reproducible and cost-effective.

Previous attempts (Ohlemiller 1995) to develop benchscale methods to predict the immediate response of a mattress to flaming ignition source had failed. Flame spread and ignition properties measured using bench-scale test (Babrauskas 1981) protocols failed to characterize mattress behavior consonant with full scale tests. Testing

Table 10 Description of FR modified bedding assemblies and FR bedclothes (Ohlemiller \& Gann 2003)

\begin{tabular}{|c|c|c|c|c|c|c|}
\hline \multirow[t]{2}{*}{ Bedding assembly* } & \multirow[t]{2}{*}{ Protective skirt } & \multicolumn{5}{|c|}{ Description of bedclothes } \\
\hline & & Mattress pad & Comforter & Pillow & $\begin{array}{l}\text { Fitted, flat sheets, } \\
\text { and pillowcase }\end{array}$ & Blanket \\
\hline । & $x$ & $\begin{array}{l}100 \% \text { polyester fiberfill and } 100 \% \\
\text { cotton shell }\end{array}$ & & & $\begin{array}{l}50 \% \text { cotton } / 50 \% \\
\text { polyester }\end{array}$ & 100\% acrylic \\
\hline$\|$ & $x$ & Blend of charring and non-charring fiberfill & \multirow{2}{*}{\multicolumn{2}{|c|}{ FR polyester fill }} & & \\
\hline III & $\sqrt{ }$ & & & & & \\
\hline IV & & \multirow{2}{*}{\multicolumn{3}{|c|}{$\begin{array}{l}100 \% \text { polyester fiberfill and charring barrier } \\
\text { fabric (type 1) under } 100 \% \text { cotton shell }\end{array}$}} & & \\
\hline V & $\sqrt{ }$ & & & & & \\
\hline VI & & $\begin{array}{l}100 \% \text { polyester fiberfill and charring barrier } \\
\text { fabric (type 2) under } 100 \% \text { cotton shell }\end{array}$ & & & & \\
\hline VII & $\sqrt{ }$ & & & & & \\
\hline
\end{tabular}

${ }^{*}$ Bedding assembly includes mattress set (mattress and foundation) and bedclothes including protective skirt, mattress pad, two bed sheets, pillow with a pillowcase, blanket, and a comforter. 
of abbreviated composite of the mattress or mattress/ foundation assembly (Ohlemiller 1995) was deemed impractical and uneconomical due to limitations of specially constructed samples and their reproducibility. Moreover, the fire hazard from bedclothes cannot be ignored and further research is warranted.

The future bench scale testing methods should be based on simple but scientifically sound principles that may be employed for screening of materials. Bench scale flammability tests are useful in that several material fire properties can be derived and the data can be used for relative ranking of materials. Another potential approach is to use data from bench scale tests in mathematical models to predict large scale fire behavior. However, at the present time predictive testing has too many unquantifiable variables, and so it will likely remain a research tool in the near-term future.

\section{Abbrevations}

ASTM: ASTM International; BHFTI: Bureau of Electronic and Appliance Repair, Home Furnishings and Thermal Insulation; Cal TB: California Technical Bulletin; CFR: Code of Federal Regulation; CPSC: Consumer Product Safety Commission; EPD: Environmental Product Development; EHS: Environment, Health, and Safety; FR: Flame Retardant; FIGRA: Fire growth rate index; HR: Heat Release; HRR: Heat Release Rate; NIST: National Institute of Standards and Technology; PHRR: Peak heat release rate; PUF: polyurethane foam; REACH: Registration, Evaluation, Authorization and Restriction of Chemicals; THR: Total heat released; TTP: Time to peak heat release.

\section{Competing interests}

The authors declare that they have no competing interests.

\section{Authors' contributions}

SN carried out literature review, data analysis and drafted the manuscript. $\mathrm{RD}$ and $\mathrm{KB}$ participated in sequence alignment. All authors read and approved the final manuscript.

Received: 20 March 2012 Accepted: 27 July 2012

Published: 21 August 2012

\section{References}

Ahrens M (2011a) Smoke Alarms in U.S. Home Fires. National Fire Protection Association. Summary available from: http://tkolb.net/FireReports/2011/SmokeAlarms05-09.pdf

16 CFR 1632 Standard for the flammability of mattresses and mattress pads (1991) Consumer Product Safety Commission. Available from: http://www.cpsc.gov/businfo/testmatt.pdf

(1994) 16 CFR 1210 Safety Standard for cigarette lighters. Consumer Product Safety Commission

Hall JR (2012) The smoking-material problem. National Fire Protection Association Fire Analysis and Research, Quincy, MA, http://www.nfpa.org/assets/files/PDF/OS.Smoking.pdf

Tohamy SM, Aiken DV (2007) Assessing regulatory effectiveness with exogenously declining risk: A case study of the CPSC's 1973 mattress standard. Journal of Safety Research 38:661-668

Ahrens M (2011b) Home structure fires. National Fire Protection Association. Summary available from http://www.nfpa.org/assets/files/pdf/os.homes.pdf

Ahrens M (2008) Home fires that began with upholstered furniture. National Fire Protection Association. Summary available from: http://www.nfpa.org/ assets/files/PDF/UpholsteredExecutiveSum.pdf

Greene M, Miller D (2010) 2006-2008 Residential Fire Loss Estimates. Consumer Product Safety Commission report. Available from: http://www.cpsc.gov/library/fire06.pdf

Fleischmann CM (2006) Flammability tests for upholstered furniture and mattresses. In: Apte VB (ed) Chapter 7 in Flammability Testing of Materials used in Construction, Transport and Mining. Woodhead Publishing, Cambridge, UK, pp 164-186

Babrauskas V, Peacock RD, Reneke PA (2003) Defining flashover for fire hazard calculations. Part II Fire Safety J 38:613-622

Ohlemiller TJ, Gann RG (2002) Estimating reduced fire risk resulting from an improved mattress flammability standard, NIST Technical Note 1446. National Institute of Standards and Technology, Gaithersburg MD

BS 6807 (2006) Methods of test for assessment of ignitability of mattresses, upholstered divans and upholstered bed bases with flaming types of primary and secondary sources of ignition. British Standards Institution, London

BS EN 597 (1995) Furniture: Assessment of the ignitability of mattresses and upholstered bed bases. British Standards Institution, London

16 CFR 1633 (2007) Standard for the flammability (open flame) of mattress sets. Consumer Product Safety Commission. Available from: http://www.cpsc.gov/businfo/frnotices/fr06/mattsets.pdf

BS 7177 (2999) Specification for resistance to ignition of mattresses, mattress pads, divans and bed bases. British Standards Institution, London

(1979) Method of test for combustion resistance of mattresses-cigarette test. Method 27.7, National Standard of Canada CAN2-4.2-M77

Ohlemiller TJ, Shileds J, McLane R, Gann R (2000) Flammability assessment methodology for mattresses, NIST Internal Report 6497. National Institute of Standards and Technology, Gaithersburg MD

Ohlemiller TJ (2003) Flammability test of full-scale mattresses: Gas burners versus burning bedclothes, NIST Internal Report 7006. National Institute of Standards and Technology, Gaithersburg MD

(2005) Issues associated with the possible revocation/amendment of 16 CFR 1632, the Standard for the flammability of Mattresses and Mattress Pads. Log of Meeting, Directorate for Engineering Sciences, Available from: http://www.cpsc.gov/library/foia/meetings/mtg06/MattressOct20.pdf

BS EN 14533 (2003) Textiles and textile products. Burning behaviour of bedding items, Classification scheme

(2007a) U.S. national estimates of fires, deaths, injuries, and property losses from unintentional fires, U.S. Consumer Product Safety Commission, Washington, DC

U.S. Fire Administration National Fire Data Center (2008) (2008) National Fire Incident Reporting System 5.0 Complete Reference Guide. January 2008, available at: http://www.usfa.fema.gov/downloads/pdf/publications/ nfirs_data_analysis_guidelines_issues.pdf

Smith LE, Greene MA, Singh HA (2002) Study of the effectiveness of the US safety standard for child resistant cigarette lighters. Injury prevention 8:192-196

Smith L, Smith C, Ray D (June 1991) Lighters and matches: an assessment of risk associated with household ownership and use. US Consumer Product Safety Commission, Washington, DC

(2007b) National Fire Incident Reporting System (NFIRS) data in Fire in United States 1995-2004, Fourteenthth edn., p FA-311

(2002a) Mattress and bedding fires in residential structures. US Fire Administration Topical Fire Research 2(17)

Nurbakhsh S, Mc Cormack J (1998) A review of the Technical Bulletin 129 full scale test method for flammability of mattresses for public occupancies. Journal of Fire Sciences 16:105-124

Tohamy SM (2004) Preliminary regulatory analysis of a draft proposed standard to address open-flame ignitions of mattresses

Ohlemiller TJ (2005) A study of size effects in the fire performance of beds, NIST TN 1465. National Institute of Standards and Technology, Gaithersburg MD

Ohlemiller TJ, Gann RG (2003) Effect of bed clothes modifications on fire performance of bed assemblies, NIST Technical Note 1449. National Institute of Standards and Technology, Gaithersburg MD

Butler KM, Ohlemiller TJ, Shileds JR (2999) The contribution of bedding fires, unpublished report

(2999a), http://www.bhfti.ca.gov/

(2999b), http://ulstandardsinfonet.ul.com/sot/m2060_2,1895_2,20021230_sum.html

Mattress manufacturing in the US (2011) Market research report

Taylor D (2999) Single-sided vs. double-sided mattress comparisons. http://www.ehow.com/about_5640316_single_sided-vs_-double_sidedmattress-comparisons.html

Nazare S, Davis R (2011) A review of fire blocking technologies for soft furnishings, NIST Technical Note 1728. National Institute of Standards and Technology, Gaithersburg MD 
Wakelyn PJ, Adair PK, Barker RH (2005) Do open flame ignition resistance treatments for cellulosic and cellulosic blend fabrics also reduce cigarette ignitions? Fire and Materials 29:15-26

Toxicological Risks of Selected Flame Retardant Chemicals (2000) National Research Council. National Academy of Sciences, US

(2999c), http://www.alessandrayarns.com/about.html

Sundström B (2007) The development of a European fire classification system for building products:Test methods and mathematical modeling. Doctoral Thesis, Department of Fire Safety Engineering, Lund University, Sweden, Lund, Available from: http://www.sp.se/en/publications/Sidor/ Publikationer.aspx?Publld=10123

Nazare S, Kandola BK, Horrocks AR (2002) Use of cone calorimetry to quantify the burning hazard of apparel fabrics. Fire and Materials 26:191-199

Damant GH, Nurbakhsh S (1992) Heat release tests of mattresses and bedding systems. Journal of Fire Sciences 10:386-410

Technical Bulletin 117 (2000) Requirements, Test Procedure and Apparatus for Testing the Flame Retardance of Resilient Filling Materials Used in Upholstered Furniture. State of California Department of Consumer Affairs Bureau of Home Furnishings and Thermal Insulation, 3485 Orange Grove Avenue North Highlands, CA, pp 95660-5595

Technical Bulletin 121 (Flammability Test Procedure for Mattresses for Use in High Risk Occupancies) Flammability Test Procedure for Mattresses for Use in High Risk Occupancies. Available from: http://www.bhfti.ca.gov/industry/ bulletin.shtml

Bwalya A, Gibbs E, Lougheed G, Kashef A, Saber H (2009) Combustion of non-openflame resistant Canadian Mattress in a roon environment. Fire and Materials Conference, 12th International Conference, San Francisco, CA, pp 26-28, January 2009, pp. 1-2. Also available at: http://irc.nrccnrc.gc.ca

Babrauskas V (1977) Combustion of mattresses exposed to flaming ignition sources Part I. Full-scale tests and hazard analysis, NBSIR. National Bureau of Standards, Washington D.C, pp 77-1290

Babrauskas V (1981) Combustion of mattresses exposed to flaming ignition sources Part II. Bench-scale tests and recommended standard test, NBSIR. National Bureau of Standards, Washington D.C, pp 80-2186

(2007c) Evaluation of tick construction/finish during mattress open flame testing Report number 07-31. Precision Custom Coatings LLC, 200 Maltese Drive Totowa, NJ, p 07512

Horrocks AR, Kandola B, Padmore K, Dalton J, Owen T (2001) Comparison of cone and OSU calorimetric techniques to assess the flammability behaviour of fabrics used for aircraft interiors. Proceedings of the 7th Fire and Materials Conference, San Francisco, U.S.A, p 231

Fritz TW, Hunsberger PL (1997) Testing of mattress composites in the cone calorimeter. Fire and Materials 21:17-22

Technical Bulletin 129 (1992) Flammability Test Procedure for Mattresses for Use in Public Buildings. State of California Department of Consumer Affairs Bureau of Home Furnishings and Thermal Insulation, 3485 Orange Grove Avenue North Highlands, CA, pp 95660-5595

Breese JN (1977) Tests on Insulative Barriers as a Method of Protecting Neoprene Core Mattresses. NBSIR771295. National Bureau of Standards, Washington D.C

(2999d) National estimates based on data from the National Fire Incident Reporting System (NFIRS) (1996-1998) and the National Fire Protection Association's (NFPA's) annual survey. Fire Loss in the United States

(2002b) Mattress and bedding fires in residential structures, U.S. Fire Administration Topical Fire Research Series 2(17), Available from: http://www.usfa.fema.gov/downloads/pdf/tfrs/v2i17.pdf

Flammability (2999) The issue heats up. Part 2 Fire safety \& the bedding industry. Available from: http://www.safesleep.org/pdf/december2001.pdf

Woolley WD (1976) Fire behavior of beds and bedding materials. Fire and Materials 1:63-73

Palmer KN, Taylor W, Paul KT (1975) Fire hazards of plastics in furniture and furnishings: Fires in furnished rooms, CP 21/76. Building Research Establishment, Borehamwood

Gawande Nazaré S (2002) Investigation and prediction of factors influencing flammability of nightwear fabrics, PhD Thesis. University of Bolton, Bolton, UK

Ohlemiller TJ (1995) An examination of the correlation between cone calorimeter data and full-scale furniture mock-up fires. Proceedings of the International Conference on Fire Research and Engineering, Orlando, $\mathrm{FL}$, pp 10-15

ASTM E1590-12 (2999) Standard Test Method for Fire Testing of Mattresses (2999e), http://www.originalmattress.com/classic/comfort-choices; last viewed on February 24, 2012

doi:10.1186/2193-0414-1-2

Cite this article as: Nazaré et al:: Assessment of factors affecting fire performance of mattresses: a review. Fire Science Reviews 2012 1:2.

\section{Submit your manuscript to a SpringerOpen ${ }^{\odot}$ journal and benefit from:}

- Convenient online submission

- Rigorous peer review

- Immediate publication on acceptance

- Open access: articles freely available online

- High visibility within the field

- Retaining the copyright to your article

Submit your next manuscript at $>$ springeropen.com 